\title{
Does online retail coupons and memberships create favourable psychological disposition?
}

\begin{abstract}
This study aims to examine the impact of coupons, portal membership and peer-influence on consumer purchase and psychological actions, which is built on the theory of impulsiveness and the theory of dissonance. The study uses $2 \times 2 \times 2$ (i.e. coupons, peer influence, complimentary coupons) factorial experimental design to investigate the proposed hypothetical model. The experiment was conducted with 364 participants. The study used a two-step structural equation modelling analysis to validate the proposed hypothetical model. The findings suggest that an increase in coupons can positively enhance the purchase actions and impulsiveness, which can later influence cognitive post purchase dissonance (CPPD) and affective post-purchase dissonance (APPD), as well as customers repurchase intention. It was also found that providing additional complimentary coupons reduces the effect of CPPD but not of the APPD. This study contributes to dissonance theory by adding APPD into the framework; moreover, the results on the coupons, memberships and peer influence will offer further insights to practitioners.
\end{abstract}

Keywords: Online coupons; impulsive purchases; post-purchase dissonance; online subscriptions and memberships; social influence; repurchase intention.

Balakrishnan, J. Foroudi, P., and Dwivedi, Y.K. (2020) Does online retail coupons and memberships create favourable psychological disposition? Journal of Business Research. 


\section{Introduction}

Traditional marketing tools have used coupons to attract new buyers in the product line (Blattberg and Neslin, 1990). The same phenomenon is extended in online retailing businesses to attract and sustain the new and existing customers (Oliver and Shor, 2003; Ravula et al., 2020). A report says that $60 \%$ of the online shoppers worldwide look for any digital coupons before their purchases (Clement, 2019). Among many phenomena that are influencing purchases in online retailing platform, the notable developments include promotional schemes (Grewal et al., 2011; Carlson and Kukar-Kinney, 2018) and peer influence (Lee et al., 2011) in e-commerce portals. Whereas, the recent developments in promotional schemes include marketer's effort to supply e-coupons and influence portal membership strategies to garner attention among the consumers. Portal memberships refer to customer enrolment to membership programs in e-commerce portals to receive exclusive benefits. E-commerce websites have started using membership advantage for its customers. Prime membership is one such example, through which Amazon offers various benefits to its customers to increase their online value propositions. According to a statistic, it was predicted that $60 \%$ of prime users in Amazon spent $\$ 6000$ on an average every year (muchneeded.com, 2020).

Previous studies have investigated different phenomenon associated with e-coupons such as; redeeming coupons (Oliver and Shor, 2003; Dickinger and Kleijnen, 2008), location based coupons (Souiden et al., 2019), usage intention (Kang et al., 2006), and coupon effectiveness (Reichhart et al., 2013). But there are no studies that has directly established a link between e-coupon values and purchases. Likewise, previous research has found that online memberships (Qu and Lee, 2011; Phua et al., 2017), category memberships (Bolton et al., 2000), offline memberships (Moon et al., 2008) can significantly build purchase intention. But to our knowledge, no studies have attempted to investigate the impact of online portal memberships on customer purchases. In the same line, it is important to study the role of peer influence in online purchases (Hu et al., 2016). Given the rise of social shopping websites, peer influence in purchase area has become inevitable for the buyers (Hajli et al., 2017). Previous studies have investigated different phenomena associated with peer influence such as decision-making styles (Niu, 2013), purchase decisions (Hu et al., 2016; Zhu et al., 2016), and trust (Hajli et al., 2017). Building from the above gaps, this study aims to identify the relationships between coupon value, portal membership, peer influence, and customer 
purchase value. The study also aims to understand how these variables can build impulsiveness among the consumers.

Alexander et al. (2015) in their research found that coupon usage can elicit physiological reactions. Previous studies have supported that promotional activities (Pechmann et al., 2005) and peer influence (Luo, 2005) increases impulsive purchases. Plethora of studies have supported that online shopping is more prone to impulsive purchases (Verhagen and van Dolen, 2011; Wells et al., 2011; Khachatryan et al., 2018) for various reasons. But no study has directly attempted to investigate the relationship of coupons and portal membership towards impulsiveness, except a study by $\mathrm{Xu}$ and Huang (2014) which found that price discount factors can influence impulsive actions. By exploring these relationships, this study adds value to marketing promotions literature and also opens a new forum for discussion on the concept of 'portal membership'. More than understanding the factors that induce impulsiveness, it is important to explore the consequences of such action. Dholakia (2000) in their research proposed that impulsive purchases tend to have cognitive enactments. Any post-purchase cognitive judgements will result to a dissonance state (Sweeney et al., 2000). Building upon this proposition, it is important to understand on whether impulsive purchases create dissonance during an online coupons purchase, because this may hinder marketers aim to create sustainable purchases among customers. Previous studies have supported that dissonance can negatively influence repurchase intention (Wilkins et al., 2016). Building from the above arguments and gap, present study proposes the following research questions.

$R Q$ 1: What is the role of e-coupons, portal membership and peer influence towards purchase behaviour and consumer psychological states (impulsiveness and dissonance)?

$R Q$ 2: What is the effect of these psychological state (impulsiveness and dissonance) on consumer repurchase intention?

By exploring these research questions, we anticipate providing a valid theoretical contribution and a greater practical understanding. Present study derives its arguments from theory of reasoned action (TRA), consumer socialisation theory (John, 1999), theory of impulsiveness (Ainslie, 1975), and theory of dissonance (Festinger, 1957). Deriving from TRA, Shimp and Kavas (1984) in their study found that coupons usage can influence consumer behaviour. Present study findings will extend the previous finding of TRA related to coupons and behaviour by investigating the relationship between coupon value and purchase value. Ainslie (1975) in his theory postulated the effect of specious rewards on 
impulsiveness. Research in impulsiveness has investigated various aspects of marketing functions, but its application in marketing promotional ground is scarce and no research is available respective to e-coupons. Present research will enhance the theoretical understanding on e-coupons and its impact on impulsiveness and thus contributes to the literature pertaining to impulsiveness. Also, this will be value addition to the literature that supports that promotional activities can enhance impulsiveness (Pechmann et al., 2005). More importantly consumer socialisation theory (John, 1999) proposed that socialisation can affect consumer decision making strategies. Most of the studies built from this theory is more focussed to understand consumer attitude. Present research contributes to this theory by investigating the relationship between online peer influence with purchase value and impulsiveness. Since there is not considerable information available regarding the role of online memberships, our findings will give future research directions to build their arguments based on the results and insights from this study. Research related to dissonance theory has not given considerable attention to affective post purchase dissonance in equivalent to cognitive post purchase dissonance. The study results will distribute the idea of dissonance theory in cognitive and affective grounds, which subsequently extends the existing theories related to dissonance and marketing. Lastly, the path between impulsiveness and dissonance has received very less exploration. By integrating the path between impulsiveness and dissonance, the study extends the previous knowledge available in impulsiveness and dissonance theories. Besides theoretical contribution, the study also provides valuable insights to marketers and retailers with practical viewpoints on how to gauge benefits through the results generated by this study.

The remaining part of the study is structured as follows: First, the relevant literature and conceptual model is proposed. Second, to test the hypothetical model, the study employed a $2 \times 2 \times 2$ (i.e. coupon value $\mathrm{x}$ peer influence $\mathrm{x}$ complimentary coupons) pre-validated factorial experimental design conducted with 364 samples. Third, the analyses and results are presented. Finally, the study results are discussed from a theoretical and practical angle.

\section{Theoretical background}

\subsection{E-coupons}

Coupons serve both as a promotional element and as an alternative form of payment value for customers (Blundo et al., 2005). Webster (1965) in his study introduced the use of coupons with respect to deal proneness. Though plethora of studies are available to support the usage 
of coupons and its benefits to marketers in traditional marketplace (Blattberg et al., 1978; Shimp and Kavas, 1984; Chiang, 1995), Fortin (2005) supported the use of coupons in cyberspace environment. Kang et al. (2006) defines e-coupons as virtual coupons that are distributed in internet for the purpose of redeeming it during online purchases. Kang et al. (2006) proposes three benefits of e-coupons compared to traditional coupons such as: (1). convenience in acquiring and redeeming it, (2) longer validity of the e-coupons, and (3) less cost in acquiring e-coupons. Since the growth of m-commerce, the concept of e-coupons has extended its scope to m-coupons (Dickinger and Kleijnen, 2008; Li et al., 2019). E-coupons can induce both positive and negative effect, it all lies with the fairness of the discount. In online retailing e-coupons are mainly circulated as scratch-code based coupons, e-mail coupons, promotional coupons, etc. Oliver and Shor (2003) in their study identified that fairness in e-coupons can induce intention to redeem it during online purchases. Recent studies have examined various aspects of coupons such as redemption (Mills and Zamudio, 2018), location-based coupons (Souiden et al., 2019), simulating targeted reminders (Li et al., 2020), coupon effectiveness (Poisson, 2018), coupon and pricing (Pandey and Maheshwari, 2017), and coupon preferences (Spralls III et al., 2016; Ferrer-Gomila et al., 2018). Most of the studies have targeted the redemption activities of the coupons. A recent study by Nayal and Pandey (2020) performed a meta analytic review on e-coupon redemption intention that has suggested that testing e-coupon performance using new theoretical models particularly in an emerging economies would be fruitful. Also, the literature reviews on this topic (Pandey and Maheshwari, 2017; Nayal and Pandey, 2020) has outlined the following research gaps that is in line with the argument presented in our study: (1) digital coupon price value and its impact on purchase; (2) identifying the negative impact of digital coupons; and (3) testing the impact of digital coupons in developing economies. In line with the discussion presented above, our study attempts to investigate the effect of e-coupon value in creating impulsiveness and purchase value in the context of India as an emerging economy.

\subsection{Peer influence and portal membership}

The term "Peers" refer to a group who represents similar knowledge, experience, and ideology with each other (Newman, 1982). Previous studies have supported that peers play a strong role to influence people during purchases (Bearden and Etzel, 1982). Niu et al. (2013) extended the same in online buying scenario. Studies have attempted to investigate the impact of social/peer influence on buying patterns and impulsive actions (Rook and Fisher, 1995). The fundamental ideology behind the peer inference is derived from social influence theory 
(Amblee and Bui, 2011). The theory proposes two level of social influence streams. The first stream was introduced by Deutsch and Gerard (1955) which states that social influence involves both informational and normative branches. The second stream was extended in the study by Kelman (1958), which states that social influences can bring attitudinal change through compliance, identification, and internalisation. Previous studies have found that both informational and normative social influence can positively influence impulsive behaviour during online buying (Hu et al., 2019). Huang (2016) in his recent study connected social capital and flow theory to find the experiential effect of social influence towards online impulsive buying. This study extends in the same line to understand the impact of peer influence towards impulsive buying. Portal memberships is a well-known strategy followed by online marketplace companies to retain their customer. "Amazon prime membership" is a good example to illustrate how Amazon attempts to create engagement and retain its customers by offering multiple cross-functional benefits. As of March 2019, Amazon Prime has 103 million subscribers in the United States (Statista, 2019). Despite the growth of Amazon Prime, no previous studies have investigated the effect of this growth in relation to psychological effects. A recent study by Wayne (2018) explained the importance of prime membership. The study also practically supported that prime membership could influence higher purchases. Similar to, prime membership, almost all e-commerce has started portal membership to create more sustainable activity. But no solid attention was given to investigate such membership influences. This study investigates the impact of portal membership towards purchases and impulsive actions.

\subsection{Theory of Impulsiveness}

Stern (1962) explains impulsive purchases are made without any prior planning. Bellenger et al. (1978) explain that impulsive purchases mostly arise after a customer enters the store. Based on this connection, most of the research have investigated the relationship between sales promotion and impulsiveness. Stern (1962) in his framework proposed that pure impulsiveness is instantaneous, while reminder impulsiveness involves recalling any previous memory. Previous research strongly posits that impulsiveness is mainly derived from economic and social factors (Rook and Fisher, 1995). Coupon purchases can involve both pure and reminder impulsive purchases. Previous studies have emphasised that impulsiveness is mainly driven through reward seeking behaviour (Ainslie, 1975), whereas other scholars support coupons as a rewarding phenomenon for consumers (Ashworth et al., 2005). While coupons can induce impulsiveness, the consequence following that is not well explored. 
Dholakia (2000) in his study found that marketing stimuli can positively enhance impulsive purchases. Similarly, as mentioned earlier social influence can also lead to strong impulsive purchases. While most of the research have investigated the precursors of impulsive purchases, very limited studies have given importance to consequences of impulsive purchases. Research related to impulsiveness have supported that impulsive purchases are more connected with emotional regulation (Fenton-O'Creevy et al., 2018), the same can impact on negative consequence. Notably, George and Edward (2009) in their study supported that impulsive purchases will upscale the cognitive dissonance felt. Another research by George and Yaoyuneyong (2010) supported the same by employing student sample. However, no existing study has examined yet the relationship between impulsive purchases towards cognitive and affective dissonance.

\subsection{Theory of Dissonance}

The theory of dissonance states that people go through different, even conflicting experiences during the decision-making process (Festinger, 1964). The same applies to the consumer decision making process (Cummings and Venkatesan, 1976; Mellinas et al., 2019). No research so far has attempted to build a comprehensive framework using both the behavioural theory of impulsiveness and the theory of dissonance in the context of marketing and promotions. Especially in recent years, marketing research have received little attention from dissonance related studies (Tanford and Montgomery, 2015; Wilkins et al., 2019). According to the cognitive dissonance theory, the inconsistency between human cognitive beliefs and the action may lead to a state of dissonance (Festinger, 1957). Cognitive post purchase dissonance (CPPD) arises when there is a conflict between thinking and action related to their purchase behaviour (Sweeney et al., 2000). Consumers planning may encompass around various benefit accumulation (Kumar and Reinartz, 2016) by reducing the both tangible and intangible costs associated with the product or service. In such situations, consumers mainly seek to coordinate their purchase behaviour rationally. Human responses are naturally streamlined through various cognitions and emotions (Elliot and Devine, 1994). Most of the literature has discussed post purchase dissonance as one of the psychological responses that consumers may think or feel after an unfruitful purchase event (George and Yaoyuneyong, 2010). The same can negatively infect other consequential actions like repurchase intentions, loyalty, and word of mouth (Wilkins et al., 2016). Most of the research and reviews have addressed the concept of post purchase dissonance as a cognitive function (Cummings and Venkatesan, 1976; Santos and Boote, 2003; George and Yaoyuneyong, 2010; Wilkins et al., 
2016) as opposed to an affective function. 'Think and feel' are integral parts of any consumer actions (Fournier, 1998). Yet, thinking can lead to more rational decisions, whereas feeling can lead to emotional decisions. Marketing literature has addressed cognitive actions and affective actions as a function of think and feel (Mayer and Tormala, 2010). Still, the concept of emotional/affective dissonance is considerably addressed in the context of human resource studies (Karatepe and Uludag, 2007; Lewig and Dollard, 2003). More precisely, the feel of dissonance after purchase is known as affective post purchase dissonance (APPD). Similar to inconsistency in thinking, consumers may also feel imbalanced after their purchase actions emotionally, or by an affective attitude. This research is more tuned to understanding how both CPPD and APPD plays a role in creating higher repurchase intention.

\section{Conceptual model and hypotheses}

The conceptual model proposed in this study is built from the arguments derived from Theory of Reasoned Action (TRA), Consumer Socialisation Theory (John, 1999), Theory of Impulsiveness (Ainslie, 1975), and Theory of Dissonance (Festinger, 1957). Though some studies have provided insights on the relationship between sales promotion and impulsiveness, no strong explanation is provided in previous studies about the psychological consequences. According to Beatty and Ferrell (1988), the tendency of impulsiveness can be explained through two phenomena; “(1) to experience spontaneous and sudden urges to make on-the-spot purchases, and (2) to act on these felt urges with little (conscious) deliberation or evaluation of consequence" (p. 174). The objective of coupons and other sales promotions is to induce on the spot sales, rather than create a relationship-oriented marketing (Buil et al., 2013). Given the definition of impulsiveness, there is a strong possibility that coupons and other sales-oriented promotions can induce impulsiveness. Online portal membership/subscriptions constitute a good example for such relationship-oriented promotions. While there is a contrasting difference between coupons and online portal memberships in terms of long-term orientation, there are some affinities in terms of creating functional benefits. Shimp and Kavas (1984) in their study found that coupons usage can influence consumer behaviour. To derive this argument, Shimp and Kavas (1984) employed TRA to propose that the coupons usage can mostly determine their purchase decisions. These are marketing stimuli, yet peer influence is a social stimulus which garners a lot of research attention with respect to creating impulsiveness (Luo, 2005; Hu et al., 2019) and increasing purchases (Baumeister, 2002; Silvera et al., 2008; Wang et al., 2019). Consumer socialisation theory (John, 1999) proposed that socialisation can affect consumer decision making 
strategies. However, little is known about how these may follow a pattern in online purchases. Given the above explanation, the current study proposes a conceptual framework within which coupons, online portal memberships, and social influence can lead to more impulsive and purchase actions. A number of negative consequences of impulsiveness are identified in psychology literature, but the same pattern is not experimented in marketing context (Rook and Fisher, 1995; Fenton-O'Creevy et al., 2018). George and Yaoyuneyong (2010) in their study reveal that impulsiveness can create a positive dissonance state, which in turn can affect the purchase behaviour. Building further upon this study, one can explain how impulsiveness and purchases can influence the dissonance state. More importantly, considerably less attention has been paid to affective post purchase dissonance in both psychological and marketing literature. Although prior literature has addressed that post purchase dissonance may affect repurchase intentions, no study has offered yet any suggestion or model to overcome such a scenario (Halstead and Page, 1992). Especially given the growth of online retail sector and the diversified promotional mix offering, a framework incorporating the above gap in an online retail setting would be useful to develop and examine. In this context, the present study builds a holistic model after considering necessary gaps in the literature with manoeuvring through a strong theoretical base. Figure 1 shows the hypothetical model proposed in this study.

\subsection{Theory of Impulsiveness}

\subsubsection{Coupons on purchase value and perceived impulsiveness}

Online coupons are mostly used to avail a specified discount on the end transaction amount by using a coupon code (Suri et al., 2004; Drossos et al., 2015). Consumers try to optimise the best value for a deal, and this may derive from both psychological and functional benefits (Kumar and Reinartz, 2016). Similarly, coupons exhibit a high value proportion through functional and psychological ways (Park et al., 2011). Previous studies have addressed the role of promotions and their effect on purchase value (Krishna and Shoemaker, 1992; Barat and Paswan, 2005; Jia et al., 2018). Similarly, coupons can create an urge among consumers to redeem the coupon, while in parallel an increase in coupon value can motivate consumers to purchase for a higher value (Krishna and Shoemaker, 1992). But there are no studies that have addressed the relationship between coupons and their impact on purchase value of the transaction in an experimental context in online marketplace. Marketers offer coupons with different face values to either uplift the transaction value, or to build strong brand association 
among the consumers (Mills and Zamudio, 2018). Based on the discussion above, we propose the following hypothesis:

Hypothesis 1: The increase in coupon value can positively increase the purchase value of the transaction in an online marketplace.

Previous studies have highlighted that online purchases tend to cause more impulsive actions in comparison to offline purchases (Chan et al., 2017). And, although impulsive actions in traditional environment are attributed mostly to personal characteristics and the impulsiveness of the consumer (Beatty and Ferrell, 1998), but in online environment the external stimuli are also identified to play a huge role (Zhang et al., 2006; Wells et al., 2011). In general, sales promotion can develop more unplanned purchase actions (Lo et al., 2016). However, no literature is available to better comprehend the role of coupons in impulsive action. Impulsive actions are unplanned actions which urge consumers to make a purchase decision (Youn and Faber, 2000; Hu et al., 2019). Lim et al. (2017) state three kinds of impulsive continuum, namely buying impulsiveness, urge to buy impulsively, and impulsive buying behaviour. Besides the three states suggested by Lim et al. (2017), it is also important to understand the consequences of perceived impulsiveness, that is when consumers feel or thinking that they have made impulsive purchases (Liu et al., 2013; Lo et al., 2016). We are assuming that increase in coupon value may increase the purchase transaction value; similarly, the same can enhance perceived impulsiveness among the consumers. Building upon this, the study proposes the following hypothesis:

Hypothesis 2: The increase in coupon value can positively increase the perceived impulsiveness of the consumers in online marketplaces.

\subsubsection{Peer influence on purchase value and perceived impulsiveness}

Previous literature has addressed social influence to have a stronger relationship with purchase behaviour (Hu et al., 2016). Recently, Zhang et al. (2018) supported that group influence on shopping zone will increase the spending of the customer. Shopping with peers will strongly impact on our rational thinking that influences the purchase actions (Teng and Wang, 2015). A plethora of research studies have put forward that informational and normative influence that can reshape the purchase actions of consumers (Cheema and Papatla, 2010; Bandyopadhyay, 2016). Peer influence can enhance the actions before the purchase, during purchase, and after the purchase (Ozer and Gultekin, 2015). This study is 
more concerned with examining the influence of peer members during the time of purchase. Though there is strong literature background which has discussed the positive relationship between social influence and purchase actions, the same issue is not generalised or explored in online marketplace with a special attention to peer groups. Consumers tend to purchase more when accompanied by their friends and family (Zhu et al., 2016). Especially, peers can take the role of market mavens or an active reference group which can influence consumers during their purchases (Barnes and Pressey, 2012). As a result, we propose the following hypothesis:

Hypothesis 3: Peer influence can positively increase the purchase value of the transaction in an online marketplace.

Consumer purchase decisions are coordinated as a group behaviour, rather than individual conscious actions. Simultaneously this process may lead a consumer to buy things which they did not intend originally to purchase. In other words, consumers tend to move into an impulsive continuum when influenced by peers. This study assumes that peer influence through friends and colleagues can cause an increase in consumers' perceived impulsiveness. Luo (2005) explains that the presence of another person in the purchase area leads to impulsiveness. This is consistent with research which supports that actual self-congruence may have direct negative effect on impulsiveness (Japutra et al., 2019). Literature has supported that social influence can increase impulsiveness (Rook, 1987; Rook \& Gardner, 1993, Hu et al., 2019). Rook and Fisher (1995) in their study have strongly emphasised the role of normative and social influence in creating impulsiveness. While most of the existing studies have claimed that group influence can stimulate impulsive action in traditional marketplace (Mattila and Wirtz, 2008), this study further validates the same in the online marketplace. In online marketplace the peer or reference group influence can operate either indirectly (through reviews), or directly (through an accompanying peer) in one's purchase behaviour. This research attempts to understand on whether the direct peer influence will increase the purchase value and perceived impulsiveness in online marketplace. The following hypothesis is proposed on the basis of the above discussion:

Hypothesis 4: Peer influence can positively increase the perceived impulsiveness of the consumers in the online marketplace.

\subsubsection{Portal membership on purchase value and perceived impulsiveness}


Retaining online customers has proved to be a huge challenge for marketers (Sarkar, 2011). This is mainly due to the increasing online customer journey and the competition that is rising across the omni channels (Lemon and Verhoef, 2016). As a remedial action, online portals tend to create a subscription model with added value in the pack. The membership pack offers functional benefits (such as single day delivery, price benefits, cash back, etc.) related to their transactions, as well as other accessory benefits (video streaming, live programs, etc.). Portal membership is a necessary strategy for online marketplace business to retain the customer base. There is no research available to discuss the outcome of subscription programs in an online marketplace. More than looking at loyalty as an outcome, these subscriptions may also yield transactional benefits. For example, Amazon offers products with the tag "Prime Only", which signifies that some brands or products are offered only to prime members. Similar to portal memberships in online stores, offline stores tend to offer membership programs, which significantly relate to repeated purchases. Thus, there is a strong causation between customer relationship programs and customer purchase actions (Bowen and Chen McCain, 2015; Stathopoulou and Balabanis, 2016). Besides offline customer memberships, no research has attempted to investigate the impact of portal membership on purchase value, especially in online mode. So, this study proposes the following hypothesis to investigate the same:

Hypothesis 5: Online portal membership can positively increase the purchase value of the transaction in an online marketplace.

Along these lines, the benefits which are exclusive for portal membership can act as sales promotion agenda, which simultaneously can stimulate impulsive behaviour. Liao et al. (2009) in their work discuss sales promotion where congruent benefits can result in impulsive behaviours. With the peripheral views and the follow-up targeted advertising which the portal members receive, there is more likelihood that portal members may fall into the 'trap' of impulsive actions, especially consumers who make use of any exclusive benefits available at the sales area (Chandon et al., 2000; Sarkar et al., 2011). In case of online marketplaces, the benefits and exclusive opportunities for members may motivate consumers to perform an impulsive action. In alignment with the discussion above, this study assumes that portal membership can increase perceived impulsiveness among the customers in online marketplace. Hence, we propose the following hypothesis: 
Hypothesis 6: Online portal membership can positively increase the perceived impulsiveness of the consumers in online marketplace.

\subsection{Theory of Dissonance}

\subsubsection{Purchase value and Dissonance}

There are numerous literature sources available that discusses the antecedents and consequences of post purchase dissonance (see Santos and Boote, 2003; Wilkins et al., 2019). Previous literature has demonstrated that consumers evaluate their purchase behaviour through expected value term (Heath and Soll, 1996), and not specifically with the money spent during the transaction. Consumer perceived value is derived through benefit and cost mechanism (Carlson et al., 2015) through which the satisfaction is derived (Rust and Zahorik, 1993). Mostly consumers attempt to reduce their dissonance level through increasing the value for their purchase. However, on the other hand, when the spending value increases the threshold, it may lead to a dissonance state (Okada and Hoch, 2004). Spending can infuse both emotional and cognitive actions and in both cases it may lead to dissonance state. According to hypothesis 7, the purchase value will result in high cognitive dissonance state:

Hypothesis 7: An increase in purchase value can positively increase the cognitive post purchase dissonance in online marketplaces.

Consumers tend to evaluate their purchase actions to check whether they are congruent with their planning (Gilbride et al., 2015; Hochstein et al., 2019), and any deviation from their planning may create a dissonance. Purchase actions through marketing efforts tend to create a distortion and confusion in consumers' mind, which may later build a strong dissonance. As the aforementioned hypothesis state, this study proposes that the purchase value of the consumers may increase due to marketing efforts. Similar to cognitive post purchase dissonance, affective post purchase dissonance can create distortion in consumer mind because of higher purchase value. There is prior evidence to state regarding the role of affective post purchase dissonance. But previous studies in relation to this has stated that any unpleasant emotion in purchase area will affect purchase behaviour (Sherman et al., 1997). The same can be extended and tested whether this applies for purchase value too. Building upon the discussion above, this study attempts to explore the following relationship between purchase value and APPD: 
Hypothesis 8: An increase in purchase value can positively increase the affective post purchase dissonance in online marketplaces.

\subsubsection{Impulsiveness and Dissonance.}

Previous studies have discussed the role of impulsiveness in creating post purchase dissonance (George and Yaoyuneyong, 2010). Consumer psychological state differs at three levels: pre-purchase, purchase, and post purchase stages, where cognition and affective function can overlap or dominate at each stage (Santos and Boote, 2003). Impulsive actions are more peripheral by nature and involve low level processing of decisions. The cognitive conflict may arise when a high involvement product is processed at a low level, which later may trigger conscious thoughts in customers. In case of e-commerce, Lim et al. (2017) in their research strongly posited that impulsive buying will leads to regret among the customers. Impulsive buying is more involvement oriented; lack of involvement may lead to misleading purchase decisions (Rook and Fisher, 1995). Such a situation of psychologically unprocessed or unplanned buying can lead to a cognitive inconsistency. Previous literature has shown that cognitive inconsistency can lead to dissonance state (Elliot and Devine, 1994; Thøgersen, 2004). Given the scenario that impulsiveness can be affected by instrumental and symbolic factors (Ditmar et al., 1995), consumer processing towards post purchase understanding can be multiverse. There is a strong possibility that cognitive post-purchase decision can arise in these conditions. As a result, we propose that perceived impulsiveness can increase the likelihood of CPPD:

Hypothesis 9: Perceived impulsiveness can positively increase the cognitive post purchase dissonance in online marketplaces.

While the majority of scholarly work have focussed on discussing CPPD, the affective dissonance state has attracted limited attention. Few studies have addressed the part of affective post purchase dissonance (APPD), but not as comprehensively as CPPD. The role of affective part in purchase process is considerably discussed in previous studies (Santos and Boote, 2003). The affective and cognitive parts may overlap at every stages of purchase cycle, which may create a psychological chaos. Literature has addressed that cognitive state has deeper processing than affective state (Baker et al., 2010). In this case, when a consumer performs a rational purchase action may be free from CPPD, but at the same time the presence of APPD cannot be ruled out. Psychological research has addressed affective and cognitive actions as two opposite bi-polar elements which determine human actions (Baker et 
al., 2010). This also signifies that post purchase dissonance does not need to be always an outcome of a cognitive action, as a consumer who fails to experience an affective component during the purchasing process may have APPD. Similar to, CPPD, APPD can also be a possible outcome derived from perceived impulsiveness. Hence, we postulate the following relationship:

Hypothesis 10: Perceived impulsiveness can positively increase the affective post-purchase dissonance in online marketplaces.

\subsubsection{Post purchase dissonance and repurchase intention}

The state of dissonance has become more vulnerable in recent years. Especially with the growth of online market place, consumers have a plethora of options and offers which lead to a compulsive behaviour despite strong cognitive repelling (Kukar-Kinney et al., 2016). Researchers have acknowledged that the growth of social media and web 2.0 has resulted in various changes in consumer belief patterns along with their behavioural pattern (Schlosser et al., 2006; Hong and Cho, 2011). As stated in seminal research, a conflict of beliefs or availability of options may result to the creation of dissonance state and previous research has quoted dissonance as inconsistency between one's thinking and their action (Festinger, 1957; Elliot and Devine, 1994). With marketers' focus being mainly attributed to sales conversion, the state of dissonance can affect customers' long term purchase orientation. Our earlier hypotheses reveal that coupons can influence perceived impulse actions which in turn can result in dissonance; this is again an important aspect to investigate as to whether they create a sustainable action. Previous studies have supported that dissonance can damage consumers repurchase intention (Mao and Oppewal, 2010). Hellier et al. (2003) explains repurchase intention as individual's judgement to buy the desired product from the same company again, after considering his or her current situation. Prevalence of CPPD can have a negative effect towards repurchase intention. This is mainly because humans tend to reduce their dissonance state after any action. That can subsequently stimulate their mind negatively to purchase again in the product or portal. Building upon this, we are proposing the following hypothesis:

Hypothesis 11: Cognitive post purchase dissonance can influence negatively repurchase intention in online portal.

Growing competition among the online marketplace websites has benefited consumers to avail a series of options and opportunities. While on the one side, the opportunities have 
offered freedom to consumers, on the other side, it has increased the dissonance state. This hypothesis attempts to understand how APPD contrast towards online repurchases. Earlier studies have put forward that consumers' emotions and feelings have greater impact on purchases. Lu et al. (2012) explain that consumers' emotional dissatisfaction can greatly affect the customer repurchase intention. Similar to this, Shank and Robinson (2019) support that customer emotions play a significant role in store revisit intention and repurchase intention. It is also believed that fruitful emotions can enhance purchases, but this can be reversed if there is an affective dissonance. There is no empirical understanding on how APPD operates in relation with consumer purchase behaviour. With the cues of the above discussion, we propose that APPD can negatively influence repurchase intention of the consumers through the hypothesis below:

Hypothesis 12: Affective post purchase dissonance can negatively influence repurchase intention in online portal.

\subsubsection{Effect of Complimentary coupons on post purchase dissonance and repurchase intention}

In the first part of the paper, we addressed that sales promotion and coupons may not yield a sustainable marketing solution, which otherwise may affect through a psychological conditioning of the repurchase intention of consumers. Through this hypothesis, we investigate how after-sale complimentary coupons can reduce the negative effect between CPPD with repurchase intention. Given the extensive literature collection, we were not able to find conclusive evidence on how literature has addressed this issue. Previous studies have discussed the effectiveness of post purchase programs towards customer relationship strategies (Sharp and Sharp, 1997; Hsu et al., 2015; Kumar and Reinartz, 2018). Besides this, previous research has strongly advocated that post purchase promotions or programs have a greater impact on improving brand equity (Roehm et al., 2002). Offline store and online stores use membership options to maintain a prospective customer base and to build a sustainable relationship with them. Post purchase promotions and loyalty programs majorly aim to retain their customer base (Bolton et al., 2000; Kim et al., 2019). However, previous research has addressed that cost of retention is relatively higher than the cost of acquiring (Rust and Zahorik, 1993), which is a point to ponder. Building upon this, it is a prospective path to investigate how sales promotions can be employed for post purchase promotions, which again can reduce the dissonance towards repurchase. Complimentary coupons can 
functionally benefit consumers, which in turn may decrease the CPPD state. Based on that, we are proposing the following hypothesis:

Hypothesis 13: Complimentary coupons positively moderate the relationship between cognitive post purchase dissonance and repurchase intention in online portals.

In recent years, consumers have a plethora of options and persuasion from marketers at their disposal, which otherwise turns up to be a hindrance in consistent purchase behaviour. This also enhances higher possibility for unavoidable dissonance states. Marketing is a sustainable practice, which sometimes ends up being more transactional, mainly due to large salesoriented promotions, but at the same time it is important to understand how these sale promotions may yield a sustainable practice as well. Promotional benefits tend to create positive emotions among the consumers (Barone and Roy, 2010). In the same line of thought, providing complimentary coupons may uplift the emotional imbalance that may have occurred during purchases. Building upon this, we propose that complimentary coupons can reduce the effect between CPPD and repurchase intention:

Hypothesis 14: Complimentary coupons positively moderate the relationship between affective post purchase dissonance and repurchase intention in online portals.

\section{<Insert Figure 1>}

\section{Methods}

\subsection{Design introduction and Participants}

This study attempted to investigate the role of the three experimenting variables (coupon value, peer influence, and complimentary coupons) in the above introduced hypothetical model. To administer this, the study employed experimental between-groups factorial design. 364 participants were randomly assigned to 8 blocks $(2 \times 2 \times 2)$ to investigate their purchase pattern respective to 8 different conditions. Prior to the experiment, it was confirmed that all 364 students are frequent buyers through online portals. The experiment was carried with the help of "Amazon.in" coupons. The study was conducted during the second day of a two-day inter college national competition in India. The competition received 811 students, out of which 364 students gave consent to participate in the study. It was identified that all 364 participants frequently involved in online purchases (311 participants $=$ at least once in a week; 53 participants = at least twice in a week). With more than $85 \%$ of the sample involved in online purchases at least once in a week, it can be justified as representative online buyers. 
This was conducted to confirm their representativeness in study population, and to eliminate the possibility of self-selection bias. With young consumers predominantly involved in online buying, this research has recruited participants within the age group of 18 to 37 years. The socio-demographic characteristics of the participants are provided in Table 1.

\subsection{Study design and experiment conditions}

The study followed a $2 \times 2 \times 2$ factorial design representing three experimental variables in the model namely, coupon value (Rs. 200 coupons/Rs. 100 coupons), peer influence (purchase made with peers/purchases made individually), and complimentary coupon (complimentary coupons issues/complimentary coupons not issued). For the purpose of the experimental procedure, we employed “Amazon.in” coupons worth, Rs. 100 each. The users can use this coupon to buy any products from "Amazon.in", with the coupon value being deducted from the final bill value (inclusive of shipping cost). All the three experimental variables had two conditions each: coupon value (coupon value of Rs. 200 and coupon value of Rs. 100), peer influence (participants accompanying a peer member and participants without any accompany), post-purchase complement (complementary coupon of Rs. 100 and no coupon).

\subsection{Experiment and data collection procedure}

The experiment of this study was structured in the following sequence; firstly, the participants who expressed interest in participating in the study were allocated randomly to any groups. This study received consent from 364 students to take part. The three experimental variables were assigned randomly to 8 different experimental blocks. The details of the participants in blocks, experiment intervals, and condition manipulations are available in Appendix 1.

The participants were allotted specific slot as given in Appendix 1 based on which the experimental manipulated variables were employed. For the variable: coupon value, participants were allocated according to the study manipulations and the participants were given coupon worth Rs. 200 and coupon worth Rs. 100 respective to the blocks. Among the 364 participants, 331 subjects used the coupons to make some purchases. The study participants were allowed to purchase any product of their choice. The detailed description of the products they purchased is given in Table 1. The remaining 33 participants did not wish to use the coupons and made no purchase during the experiment. For the variable: peer 
influence, a set of participants were allowed to engage in the experiment along with a peer member and the remaining participants were permitted to engage in the experiment individually without any accompanying member as per the block design. Each experiment lasted for 68 and 54 minutes respectively. The experiments were conducted in two separate time intervals in two computer laboratories. The whole research experiment was assisted by six research assistants with proper instructions. After the completion of the experiment, the third variable (complimentary coupons) was employed. In which, a set of participants were given a complimentary coupon worth Rs. 100 and another set of participants were not given any complimentary coupon and the participants were assigned according to the blocks.

A paper-based survey questionnaire was presented to the 331 participants who made any purchase during the experiment. The survey was conducted after all the experimental manipulations are completed. The questionnaire contained the questions related to the demographics and the study variables. It took an average of 15 minutes to complete the questionnaire, and all 331 eligible responses were processed forward for analysis. For the purpose of analysis, each block in the variable was coded as follows: coupon value ( 2 for Rs. 200 coupons; 1 for Rs. 100 coupons), peer influence ( 2 for participants assigned with peers; 1 for participants assigned individually), and complimentary coupons ( 2 for participants were given Rs. 100 extra coupon post purchases; 1 for no extra coupons were given post purchases).

\subsection{Questionnaire and Measures}

The questionnaire included a scale for the constructs; perceived impulsiveness, cognitive post purchase dissonance, affective post purchase dissonance, and repurchase intention along with the socio-demographic variables. All the scales were derived from previous literature and all the items were retained to fit in with this study objective. The scale for perceived impulsiveness is derived from Verhagen and van Dolen (2011) which consists of 4 items, the scale for cognitive post purchase dissonance is derived from Shahin Sharifi and Rahim Esfidani (2014), which consists of 3 items, the scale for affective post purchase dissonance is derived from Mao and Oppewal (2010) which consists of 7 items, and the scale for repurchase intention is derived from Khalifa and Liu (2007) which consists of 3 items. All the scale items are measured using a seven-point scale ranging from 'very strongly agree' (7) to 'very strongly disagree' (1). The questionnaire also includes socio-demographic variables like, gender (male/female) and portal membership (prime member/non-prime member). The 
participants were asked to mention the product category which they purchased and the total purchase value. It was identified that the participants majorly are involved across five product categories. To standardise the purchase value of the participants, the values were denoted from 7 to 1 . The details of the denoted values along with the socio-demographic variable are given in Table 1. The detailed explanation and scale information is provided in Appendix 2.

\section{<Insert Table 1 here $>$}

\subsection{Manipulations}

Prior to the main study, the experiment validation was performed using 30 participants. To validate the first experimental variable (coupon value), 15 coupons of Rs. 200 and 15 coupons of Rs. 100 each were distributed to 30 participants. All the coupons were found to be valid among the pilot sample and the participants applied the coupon in their purchases. It was identified through the independent sample $t$-test that the purchase value was significantly different across the two sample ( $\mathrm{t}=3.807$; $\mathrm{df}=28 ; \mathrm{p}<0.001$; mean difference $=$ Rs. 155.20), this validates the conditions of the first variable (coupon value) that it has significant difference in purchase value. The value Rs. 155.20 indicates the average mean difference between the two coupon values. For the second experimental variable (peer influence), 12 participants were assigned to engage in the buying activity with accompanying a peer member and the remaining 18 participants individually. Like the first variable, the conditions of the second variable (peer influence) showed a significant difference in purchase value $(\mathrm{t}=6.964 ; \mathrm{df}=28 ; \mathrm{p}<0.001$; mean difference $=$ Rs. 215.94), this validates that there is a significant mean difference in purchase value between participants accompanying peer members and participants involving individually. The value Rs. 215.94 indicates the average mean difference between the two conditions of the variable, peer difference. Finally, to validate the third experimental variable (complimentary coupons), 15 participants were given complimentary coupons of Rs. 100 post their purchases and the remaining 15 didn't receive any coupons. Finally, they were asked a question on "How would you rate your purchase experience in a five-point scale - 5 being extremely happy and 1 being extremely unhappy". The results showed that there is a significant difference in the scores obtained from the sample to which the complimentary coupons were circulated and other sample to which it wasn't circulated $(\mathrm{t}=4.437 ; \mathrm{df}=8 ; \mathrm{p}<0.001$; mean difference $=1.0)$. All the experimentation variables were found to strongly differ across their conditions. This validates the experimentation conditions more relevant to their purchase and experience. 


\subsection{Analysis}

The 331 participants who used the coupon during the purchases were considered for the further analysis. The study used two step-structural equation modelling approach. Measurement model - Confirmatory Factor Analysis (CFA) was used to confirm the validity requirements namely, content validity, convergent validity, and discriminant. On satisfactory fit of the measurement model, the constructs were tested for the hypothetical relationships using structural equation modelling. Previous studies have recommended using structural equation modelling for testing conceptual models (Fornell and Larcker, 1981; MacCallum and Austin, 2000; Gefen et al., 2000). Both CFA and structural model were tested using maximum likelihood estimation method. The fit indices along with $r^{2}$ indices of the CFA and structural model were used to evaluate the model fit. While the variables, perceived impulsiveness, cognitive post purchase dissonance, affective post purchase dissonance, and repurchase intention were measured using parametric scales; the experimental conditions coupon value, peer influence, and complimentary coupon were observed in an ordinal/categorical scale. As mentioned above, the purchase value of the participants is converted into an ordinal scale and the portal membership (prime membership/non-prime membership) is coded as nominal variable as given in Table 1. Despite the scale differences, earlier studies have supported using ordinal and interval scale in such experimentation oriented structural equation modelling studies (Edwards et al., 2012; Jöreskog and Sörbom, 1989). Finally, the factor scores of the purchase value, perceived impulsive action, APPD, CPPD, repurchase intention were checked for any mean differences across the experimental and categorical variables. The study used Microsoft Excel, SPSS 21.0 and AMOS for the analysis purpose in the study.

\section{Results}

\subsection{Measurement model}

The results of the measurement model are presented Table 2; the fit indices of the measurement model exhibited good fit which confirmed the applicability of measured items to carry to further analysis. The reliability of all the constructs as seen in table 3 , exceeded above 0.900 which confirmed that the data is free from random error. The item loadings for all the factors exceeded above 0.80 which confirmed the content validity requirements (Nunnally, 1978). Average Variance Extracted for all the factors exceeded above 0.70 with the values greater than maximum shared variance and average shared variance, this confirms 
the convergent validity of the measurement model (Fornell \& Larcker, 1981). Table 2 gives the factor loadings and AVE scores respectively. The diagonal line of table 3 represents the square root of average variance extracted for the respective construct, also it can be seen that the inter-correlation values between the respective constructs is more than $\sqrt{ }$ AVE scores. This confirms the discriminant validity requirements (Sánchez-Franco \& Roldán, 2005).

\section{<Insert Table 2 here> \\ <Insert Table 3 here>}

\subsection{Structural model}

The results of the hypothetical model are presented in Table 4. The structural equation modelling using maximum likelihood estimation investigated 14 hypotheses; the model resulted in good fit indices. The results of hypothesis 1 and 2 established coupon value to have significant relationship towards purchase value and perceived impulsiveness, of which the path between coupon value and perceived impulsiveness is identified to have higher coefficient among the both. Hypothesis 3 and 4 investigated on the relationship between peer influence and its relationship with purchase value and perceived impulsiveness, the results found that both the hypotheses are statistically significant with coefficient values less than 0.30. In a similar pattern from hypotheses 1 to 4 , hypotheses 5 and 6 investigated the relationship of portal membership towards purchase value and perceived impulsiveness, though both paths were found to have significant relationships at $99 \%$ and $95 \%$ level respectively, the path between portal membership and perceived impulsiveness is identified to have coefficient with less than 0.1 .

The results of hypotheses 7 and 8 found there is significant relationship between the purchase value of the participants towards cognitive post purchase dissonance (CPPD) and affective post purchase dissonance (APPD) with both the coefficient values ranging from 0.30 to 0.34 . Similarly, hypotheses 9 and 10 investigated the relationship between the perceived impulsiveness towards CPPD and APPD respectively, of which hypothesis 9 was found to be insignificant and the latter one is found to have significant relationship with coefficient value less than 0.20. Hypotheses 11 and 12 investigated the relationship of CPPD and APPD towards repurchase intention of participants, the results indicated that both the hypotheses were significantly with establishing a negative relationship, of which CPPD tends to have a higher negative coefficient towards repurchase intention. The $r^{2}$ values of the endogenous 
variables are given in Table 4 along with the coefficient values. Except for CPPD $\left(r^{2}=0.117\right)$ and APPD $\left(r^{2}=0.154\right)$, the remaining constructs, purchase value $\left(r^{2}=0.310\right)$, perceived impulsiveness $\left(\mathrm{r}^{2}=0.469\right)$ and repurchase intention $\left(\mathrm{r}^{2}=0.547\right)$ explained more than $30 \%$, $40 \%$ and $50 \%$ variance respectively. The validated model with results is available in Figure 2

\section{<Insert Figure 2>}

\subsection{Complimentary coupons as a moderator}

Hypotheses 13 and 14 examined the moderating effect of complimentary coupons on the relationship of CPPD and APPD towards repurchase intention. The results showed that complimentary coupon tends to significantly reduce the negative effect between CPPD and repurchase intention. Figure 3 gives a graphical understanding on the effect of the moderating variable. The slope of low complimentary coupon has no effect on CPPD towards repurchase intention, but the high complimentary coupon tends to reduce the effect of CPPD on repurchase intention. The result of hypothesis 13 implies that negative relationship of CPPD towards repurchase intention can be significantly reduced by issuing complimentary coupons post purchase. On other hand, complimentary coupons failed to moderate the relationship between APPD and repurchase intention. The same can be observed from figure 4, both the slopes namely, low complimentary coupon and high complimentary coupon do show similar slope from low to high APPD. The result of hypothesis 14 implies that providing complimentary coupons post purchases doesn't reduce the negative effect between APPD and repurchase intention. The results and its practical applications are discussed in the subsequent sections

\section{<Insert Table 4 here>}

\section{$<$ Insert Figure 3 and 4>}

\subsection{ANOVA results}

The results of ANOVA are posted in Table 5. It was found that scores of purchase value and perceived impulsive action significantly differ across the conditions of coupon value, prime membership, and peer influence, but failed to significantly differ across the condition of complimentary coupon. The scores of APPD were found to significantly differ across the conditions of peer influence but failed to significantly differ across the conditions of coupon value, prime membership, and complimentary coupon. The scores of CPPD were found to 
significantly differ across the conditions of prime membership, complimentary coupon, and peer influence, but failed to differ across the conditions of coupon value. Finally, the scores of repurchase intention exhibited a difference with complimentary coupon and peer influence, but not with coupon value and prime membership.

\section{<Insert Table 5 here $>$}

\section{Discussing the results}

The present study investigated the role of coupons, online portal membership, and peer influence in repurchase intention underpinning through psychological impacts. The experimental design was validated and a total of 364 students participated, out of which 331 engaged in purchase actions. The conceptual model in Figure 1 explains the hypotheses investigated in this study. Most of the paths in the model were identified to have significant relationship, except for the path between perceived impulsiveness and CPPD. Moreover, the complimentary coupons failed to reduce the negative impact between APPD and repurchase intention. Overall, among the 14 proposed hypotheses, 12 hypotheses were found to support the assumption made. The model fit indices showed good fit, which supported the theoretical positioning.

The results showed that an increase in coupon value can improve the purchases (hypothesis 1), and perceived impulsiveness (hypothesis 2) among consumers. The results are relatively consistent with previous research. Previous studies have identified that sales promotions have a positive effect on consumer purchases and impulsiveness (Liao et al., 2009). Kumar and Ranjan (2012) found similar results with respect to coupons. Through this, the present study narrows the previous findings of sales promotion in the context of coupons. The model also investigated peer influence and its impact on purchases (hypothesis 3) and impulsiveness (hypothesis 4). The result of hypothesis 3 is consistent with previous research (Hu et al., 2019), whereas the result of hypothesis 4 is consistent with the findings of Zhu et al. (2016) and Mattila and Wirtz (2008). Next, the path between portal membership towards purchases (hypothesis 5) and perceived impulsiveness (hypothesis 6) were not previously investigated. It was found that the increase in purchase value considerably increases the possibility of cognitive and affective dissonance (Hypotheses 7 and 8). There are no studies available to directly validate this finding, however related literature has unveiled that cognitive dissonance can arise from rational imbalance occurring during purchases (George and Yaoyuneyong, 2010). The path between impulsiveness and cognitive post purchase 
dissonance is insignificant (Hypothesis 9). On the other way, the path between impulsiveness and affective post purchase dissonance is found to be positively significant (Hypothesis 10). Both the paths were not explored previously, present research has filled this gap. More importantly, the results of the hypotheses 11 and 12 attempts to illustrate how the psychological discomfort may result in sustainable purchase actions. It was found that both cognitive and affective post purchase dissonances may result in reducing the likelihood of repurchase intention. Previous studies have found negative consequences of dissonances (Mao and Oppewal, 2010) and our research has extended the same in the context of repurchase intention. Finally, the result of hypothesis 13 suggest that by providing complimentary coupons post purchases, the effect of cognitive post purchase dissonance can be reduced significantly. Whereas the interaction between affective post purchase dissonance and complementary coupons is insignificant. This will be an added value to the literature on this topic as no study has previously examined the effect of complimentary coupons in a post purchase scenario.

Our study suggests that providing complimentary coupons can reduce the negative dissonance state. The same is demonstrated through the ANOVA results. While this study has identified that coupons can increase purchase and impulsive actions, it is inevitable that it can lead to a dissonant state. There are no empirical cues available to validate the results. But relevant research studies have identified that social experience (Liao, 2017) can reduce the post payment dissonance. Moreover, both the model hypothesis as well the ANOVA tests support that complimentary coupons cannot reduce the negative effect of affective dissonance state. Overall, the proposed model bridges the theoretical and practical perspectives on the topic. In the next sections, firstly the theoretical contributions are discussed, followed by managerial implications.

\subsection{Theoretical Contributions}

This research has introduced a framework which can add value to the literature relevant to marketing communications, consumer psychology and online omni channel promotions. More precisely the paper contributes to the following theories: theory of reasoned action (TRA), consumer socialisation theory (John, 1999), theory of impulsiveness (Ainslie, 1975), and theory of dissonance (Festinger, 1957). Deriving from TRA, Shimp and Kavas (1984) in their study found that coupons usage can influence consumer behaviour. Though their study is well acclaimed in literature relevant to coupon studies, their theory was extended 
previously with respect to purchases. This research has extended the TRA theory and the knowledge of Shimp and Kavas (1984) by adding insights that coupons can induce purchase behaviour. The study also extends the theory in online retailing setup, which can also benefit the literature which investigated the behavioural research specific to online retailing. Besides TRA, the results of e-coupons also contribute to the other marketing promotion studies (Chandon et al., 2000). Consumer socialisation theory (John, 1999) has previously addressed various social influences that can arise in a marketing scenario. This research has extended the consumer socialisation theory by finding that peer influence can impact purchase behaviour and impulsiveness. Though studies have supported that social influence will enhance purchase intention (Shiau and Luo, 2012), this study attempts to further validate that in a behavioural context. Similarly, impulsiveness has been previously found to be significantly associated with peer influence (Mattila and Wirtz, 2008), our research has reexamined this relationship in an online setup.

Besides the above mentioned two theories, theory of impulsiveness (Ainslie, 1975) is a wellknown in marketing ground. Most of the research has employed impulsiveness as an end construct to understand the effect of various stimuli on impulsiveness, this study has extended theory of impulsiveness by finding that impulsiveness can reflect negative psychological consequences. To add more value to the theory of impulsiveness, this study proposed the relationship between impulsiveness and cognitive and affective dissonance. The findings has also extended knowledge related to cognitive psychological research (Anderson, 1995) by adding that impulsiveness does not navigate through cognitive states but through affective states. The study findings also add value to theory of dissonance (Festinger, 1957) by introducing cognitive and affective states of post purchase dissonance. With almost all existing research have employed only cognitive post purchase dissonance in literature, this research has extended the knowledge by contributing affective post purchase dissonance. With specific to the relationship between impulsiveness and dissonance, the results of this model will benefit existing theories related to cognitive post purchase dissonance (Cummings and Venkatesan, 1976; Sweeney et al., 2000) and impulsiveness (Ling et al., 2010) by providing an extended information regarding their relationship. The impact of membership and its relationship with purchase behaviour and perceived impulsive actions has not been explored previously, and as such the study results opens new avenues for further exploration. The results pertaining to online portal membership and its impact in the buying psychological 
behaviour is a relatively new theory, which can contribute to further studies by facilitating framing of their arguments in a novel way.

\subsection{Managerial Implications}

Besides the theoretical contributions, this study mostly benefits those managers who try to explore new strategies to build an online sustainable platform. Through the results, it is evident that online retailers can continue adopting strategies like portal memberships. The reasons may be due to the belongingness or the functional gratifications sought, like shipping time, whereas further research can appropriately validate the same conclusions. Yet, there are omni level strategies that online marketplaces use for customer retention like mobile application incentives, greetings, wishes, etc (Verhoef et al., 2015). Lee et al. (2018) in their recent research supported that online portal memberships can help retailers to generate revenue and retain customers at the same time. The positive relationship between peer influence and purchase value indicates that retailers should focus more on to include social conversations in online portals to increase purchase behaviours. With the increasing phenomenon such as chatbots, social chat facilities can benefit the retailers. Notably, Van Dolen et al. (2007) in their paper introduced commercial group chat which can benefit retailers.

Next, the results suggest that increase in coupon value will increase the purchase value and impulsiveness. Retailers can use these as cues to issue more e-coupons to accelerate purchases among the consumers with different face value. Online coupons are distributed through various sources which can be redeemed at the source website. They can provide both functional and psychological benefits to the online shoppers. Though, impulsiveness is regarded as a problematic condition in psychological research, retailers can take it as cue to generate revenue. Marketing demands more sustainable actions to maintain cost and customers at balance. But in case of e-coupons, consumers may feel dissonant about their purchase actions. The results nearly support the same. Reducing dissonance should be an important role, since it affects the more important variables like satisfaction, loyalty, repurchase intention, etc. As the results suggested providing post purchase complimentary coupons is one of the strategies which retailers can use to reduce dissonant state among the customers. Results suggest that impulsiveness significantly increases cognitive and affective dissonance state. This is a benefit with threat situation for retailers, while they can increase the purchases with impulsiveness through coupons, but they should be aware of the 
psychological consequences thereon. Lim et al. (2017) in their research found that impulsiveness in e-commerce website may lead to regret. Present study reemphasises the same and caution the retailers in this line. With consumers' expectation towards functional and psychological benefits keep increasing, marketers are forced to implement an efficient mechanism which benefits customers.

Retailers should use efficient mechanism to generate impulsiveness without creating dissonant state. The study found that post-purchase promotions can reduce dissonance state to a considerable level. Engaging promotions after purchase in some form is essential to retain customers. Retailers can offer incentives such as cashbacks, next purchase discounts, special offers, etc, to reduce the dissonance state. In continuation to the discussion above which emphasises the marketers role in reducing dissonance state, the study found that post purchase complimentary coupons tend to reduce the negative impact between cognitive post purchase dissonance (CPPD) and repurchase intention, but fail to reduce the negative impact between affective post purchase dissonance (APPD) and repurchase intention. Cognition is a rational and analytical action which may allow consumers to mostly look into the functional benefits, but the affective part mostly deals with psychological compartment. Despite CPPD having a strong negative impact on repurchase intention; complimentary coupons were able to reduce it. This may be mainly because the investigated sample would have balanced their lack of functional benefits with the complementary coupons. This also illustrates that complimentary coupons may allow consumers to build a positive rational attitude. But this study supported that the rational inconsistency can be balanced through providing them functional benefits after sales. Whereas APPD might relate to an emotional imbalance, the functional post purchase complimentary coupons may not attract customers. This will be a fruitful area to discuss in future research studies.

\section{Conclusion, limitations and avenue for future studies}

This study attempts to analyse the effect of coupons in pre-purchase and post-purchase stages in online marketplaces. The study concludes that coupons and membership are an effective mechanism to garner high revenue, but one should beware of the psychological consequences thereafter. One of the solutions that this study attempted is to provide after purchase coupons, which can make customer happy and try to reduce the cognitive dissonance level, but not the affective dissonance part. The model validated in this study can provide benefit both in theoretical and practical terms. Overall, this study provides a direction to the marketers 
towards creating sustainable promotion strategies, in the perspective of functional and psychological functions.

While the study has some merits to discuss, some of the limitations that lie with it is that a student sample is used which can raise questions of generalizability to other age groups. Despite the fact that a student sample constitutes an effective group of online buying population, this can raise as one of the limitations of the study. The study is conducted in India, and the online buying population is growing. But a complete generalisation of the results to the global population may be a hindrance for businesses in other markets. Another limitation being, the study operated an experimental design which created a simulated setup to engage the sample during the experiment, also the study did not control any extraneous effects that may have arisen during the experiment. Future research can employ other sales promotion functions like cash backs, wallet promotions, certifications to check their performance on building long term marketing efforts. Similar models can be developed by employing different control variables. More importantly, the study has given more emphasis on affective dissonance, which however has not received equal attention to the cognitive dissonance in marketing. In general, psychology and marketing researchers can offer more well-grounded strategies to practitioners on reducing the effect of affective dissonance. The study analysed the variables in a relationship perspective, future research can attempt to divide the model in groups and perform multi group analysis to understand the precise effect of the variables on the dependent variables.

\section{References}

Ainslie, G. (1975). Specious reward: A behavioral theory of impulsiveness and impulse control. Psychological Bulletin, 82(4), 463-496.

Alexander, V., Tripp, S., \& Zak, P. J. (2015). Preliminary evidence for the neurophysiologic effects of online coupons: Changes in oxytocin, stress, and mood. Psychology \& Marketing, 32(9), 977-986.

Amblee, N., \& Bui, T. (2011). Harnessing the influence of social proof in online shopping: The effect of electronic word of mouth on sales of digital microproducts. International Journal of Electronic Commerce, 16(2), 91-114.

Anderson, J. R. (1995). Cognitive psychology and its implications (4th ed.). New York: W. H. Freeman and Company 
Ashworth, L., Darke, P. R., \& Schaller, M. (2005). No one wants to look cheap: Trade-offs between social disincentives and the economic and psychological incentives to redeem coupons. Journal of Consumer Psychology, 15(4), 295-306.

Baker, R. S., D'Mello, S. K., Rodrigo, M. M. T., \& Graesser, A. C. (2010). Better to be frustrated than bored: The incidence, persistence, and impact of learners' cognitive-affective states during interactions with three different computer-based learning environments. International Journal of Human-Computer Studies, 68(4), 223-241.

Bandyopadhyay, N. (2016). The role of self-esteem, negative affect and normative influence in impulse buying: A study from India. Marketing Intelligence \& Planning, 34(4), 523-539.

Barat, S., \& Paswan, A. K. (2005). Do higher face-value coupons cost more than they are worth in increased sales? Journal of Product \& Brand Management, 14(6), 379-386.

Barnes, S. J., \& Pressey, A. D. (2012). In Search of the "Meta-Maven": An Examination of Market Maven Behavior across Real-Life, Web, and Virtual World Marketing Channels. Psychology \& Marketing, 29(3), 167-185.

Barone, M. J., \& Roy, T. (2010). Does exclusivity always pay off? Exclusive price promotions and consumer response. Journal of Marketing, 74(2), 121-132.

Baumeister, R. F. (2002). Yielding to temptation: Self-control failure, impulsive purchasing, and consumer behavior. Journal of Consumer Research, 28(4), 670-676.

Bearden, W. O., \& Etzel, M. J. (1982). Reference group influence on product and brand purchase decisions. Journal of Consumer Research, 9(2), 183-194.

Beatty, S. E., \& Ferrell, M. E. (1998). Impulse buying: Modeling its precursors. Journal of Retailing, 74(2), 169-191.

Bellenger, D. N., Robertson, D. H., \& Hirschman, E. C. (1978). Impulse buying varies by product. Journal of Advertising Research, 18(6), 15-18.

Blattberg, R. C., \& Neslin, S. A. (1990). Sales promotion. Englewood Cliffs.

Blattberg, R., Buesing, T., Peacock, P., \& Sen, S. (1978). Identifying the deal prone segment. Journal of Marketing Research, 15(3), 369-377.

Blundo, C., Cimato, S., \& De Bonis, A. (2005). Secure e-coupons. Electronic Commerce Research, 5(1), 117-139.

Bolton, R. N., Kannan, P. K., \& Bramlett, M. D. (2000). Implications of loyalty program membership and service experiences for customer retention and value. Journal of the Academy of Marketing Science, 28(1), 95-108.

Bowen, J. T., \& Chen McCain, S. L. (2015). Transitioning loyalty programs: a commentary on "the relationship between customer loyalty and customer satisfaction". International Journal of Contemporary Hospitality Management, 27(3), 415-430. 
Buil, I., De Chernatony, L., \& Martinez, E. (2013). Examining the role of advertising and sales promotions in brand equity creation. Journal of Business Research, 66(1), 115-122.

Carlson, J. R., \& Kukar-Kinney, M. (2018). Investigating discounting of discounts in an online context: The mediating effect of discount credibility and moderating effect of online daily deal promotions. Journal of Retailing and Consumer Services, 41, 153-160.

Carlson, J., O'Cass, A., \& Ahrholdt, D. (2015). Assessing customers' perceived value of the online channel of multichannel retailers: A two country examination. Journal of Retailing and Consumer Services, 27, 90-102.

Chan, T. K., Cheung, C. M., \& Lee, Z. W. (2017). The state of online impulse-buying research: A literature analysis. Information \& Management, 54(2), 204-217.

Chandon, P., Wansink, B., \& Laurent, G. (2000). A benefit congruency framework of sales promotion effectiveness. Journal of Marketing, 64(4), 65-81.

Cheema, A., \& Papatla, P. (2010). Relative importance of online versus offline information for Internet purchases: Product category and Internet experience effects. Journal of Business Research, 63(9-10), 979-985.

Chiang, J. (1995). Competing coupon promotions and category sales. Marketing Science, 14(1), 105-122.

Clement. J (2019). "Digital coupons and deals - Statistics \& Facts". Available at https://www.statista.com/topics/2162/digital-coupons-and-deals/. Accessed on 29 February 2020

Cummings, W. H., \& Venkatesan, M. (1976). Cognitive dissonance and consumer behavior: A review of the evidence. Journal of Marketing Research, 13(3), 303-308.

Deutsch, M., \& Gerard, H. B. (1955). A study of normative and informational social influences upon individual judgment. The Journal of Abnormal and Social Psychology, 51(3), 629.

Dholakia, U. M. (2000). Temptation and resistance: An integrated model of consumption impulse formation and enactment. Psychology \& Marketing, 17(11), 955-982.

Dickinger, A., \& Kleijnen, M. (2008). Coupons going wireless: Determinants of consumer intentions to redeem mobile coupons. Journal of Interactive Marketing, 22(3), 23-39.

Dittmar, H., Beattie, J., \& Friese, S. (1995). Gender identity and material symbols: Objects and decision considerations in impulse purchases. Journal of Economic Psychology, 16(3), 491-511.

Drossos, D. A., Maragoudakis, M., \& Kokkinaki, F. (2015). Buying Behavior on Daily-Deal Sites: The Role of Face Value, Product Involvement, Information, and Website Quality. Journal of Internet Commerce, 14(2), 200-232. 
Edwards, S. M., Li, H., \& Lee, J. H. (2002). Forced exposure and psychological reactance: Antecedents and consequences of the perceived intrusiveness of pop-up ads. Journal of Advertising, 31(3), 83-95.

Elliot, A. J., \& Devine, P. G. (1994). On the motivational nature of cognitive dissonance: Dissonance as psychological discomfort. Journal of Personality and Social Psychology, 67(3), 382-394.

Fenton-O'Creevy, M., Dibb, S., \& Furnham, A. (2018). Antecedents and consequences of chronic impulsive buying: Can impulsive buying be understood as dysfunctional self-regulation? Psychology \& Marketing, 35(3), 175-188.

Ferrer-Gomila, J. L., Hinarejos, M. F., \& Huguet-Rotger, L. (2018). A survey on electronic coupons. Computers \& Security, 77, 106-127.

Festinger, L. (1964). Conflict, decision, and dissonance. Conflict decision and dissonance. Stanford: Stanford University Press.

Festinger, L. 1957. A theory of cognitive dissonance. Evanston, IL: Row, Peterson.

Fornell, C., \& Larcker, D. F. (1981). Structural equation models with unobservable variables and measurement error: Algebra and statistics. Journal of Marketing Research, 382-388.

Fortin, D. R. (2000). Clipping coupons in cyberspace: A proposed model of behavior for deal-prone consumers. Psychology \& Marketing, 17(6), 515-534.

Fournier, S. (1998). Consumers and their brands: Developing relationship theory in consumer research. Journal of Consumer Research, 24(4), 343-373.

Gefen, D., Straub, D., \& Boudreau, M. C. (2000). Structural equation modeling and regression: Guidelines for research practice. Communications of the Association for Information Systems, 4(1), 7.

George, B. P., \& Edward, M. (2009). Cognitive Dissonance and Purchase Involvement in the Consumer Behavior Context. IUP Journal of Marketing Management, 8 (3/4), 7-24

Gilbride, T. J., Inman, J. J., \& Stilley, K. M. (2015). The role of within-trip dynamics in unplanned versus planned purchase behavior. Journal of Marketing, 79(3), 57-73.

Grewal, D., Ailawadi, K. L., Gauri, D., Hall, K., Kopalle, P., \& Robertson, J. R. (2011). Innovations in retail pricing and promotions. Journal of Retailing, 87, S43-S52.

Hajli, N., Sims, J., Zadeh, A. H., \& Richard, M. O. (2017). A social commerce investigation of the role of trust in a social networking site on purchase intentions. Journal of Business Research, 71, 133-141.

Halstead, D., \& Page, T. J. (1992). The effects of satisfaction and complaining behavior on consumer repurchase intentions. Journal of Consumer Satisfaction, Dissatisfaction and Complaining Behavior, 5(1), 1-11. 
Heath, C., \& Soll, J. B. (1996). Mental budgeting and consumer decisions. Journal of Consumer Research, 23(1), 40-52.

Hellier, P. K., Geursen, G. M., Carr, R. A., \& Rickard, J. A. (2003). Customer repurchase intention. European Journal of Marketing, 37 (11/12), 1762-1800

Hochstein, B., Bolander, W., Goldsmith, R., \& Plouffe, C. R. (2019). Adapting influence approaches to informed consumers in high-involvement purchases: are salespeople really doomed? Journal of the Academy of Marketing Science, 47(1), 118-137.

Hong, I. B., \& Cho, H. (2011). The impact of consumer trust on attitudinal loyalty and purchase intentions in B2C e-marketplaces: Intermediary trust vs. seller trust. International Journal of Information Management, 31(5), 469-479.

Hsu, M. H., Chang, C. M., \& Chuang, L. W. (2015). Understanding the determinants of online repeat purchase intention and moderating role of habit: The case of online groupbuying in Taiwan. International Journal of Information Management, 35(1), 45-56.

Hu, X., Chen, X., \& Davidson, R. (2019). Social Support, Source Credibility, Social Influence, and Impulsive Purchase Behavior in Social Commerce. International Journal of Electronic Commerce, 23(3), 297-327.

Hu, X., Huang, Q., Zhong, X., Davison, R. M., \& Zhao, D. (2016). The influence of peer characteristics and technical features of a social shopping website on a consumer's purchase intention. International Journal of Information Management, 36(6), 1218-1230.

Huang, L. T. (2016). Flow and social capital theory in online impulse buying. Journal of Business Research, 69(6), 2277-2283.

Japutra, A., Ekinci, Y., \& Simkin, L. (2019). Self-congruence, brand attachment and compulsive buying. Journal of Business Research, 99, 456-463.

Jia, H., Yang, S., Lu, X., \& Park, C. W. (2018). Do Consumers Always Spend More When Coupon Face Value is Larger? The Inverted U-Shaped Effect of Coupon Face Value on Consumer Spending Level. Journal of Marketing, 82(4), 70-85.

John, D. R. (1999). Consumer socialization of children: A retrospective look at twenty-five years of research. Journal of Consumer Research, 26(3), 183-213.

Jöreskog, K. G. and Sörbom, D. (1989). LISREL 7: A guide to the program and applications. Spss Inc, Chicago.

Kang, H., Hahn, M., Fortin, D. R., Hyun, Y. J., \& Eom, Y. (2006). Effects of perceived behavioral control on the consumer usage intention of e-coupons. Psychology \& Marketing, 23(10), 841-864.

Kelman, H. C. (1958). Compliance, identification, and internalization three processes of attitude change. Journal of Conflict Resolution, 2(1), 51-60. 
Khachatryan, H., Rihn, A., Behe, B., Hall, C., Campbell, B., Dennis, J., \& Yue, C. (2018). Visual attention, buying impulsiveness, and consumer behavior. Marketing Letters, 29(1), 2335 .

Khalifa, M., \& Liu, V. (2007). Online consumer retention: contingent effects of online shopping habit and online shopping experience. European Journal of Information Systems, 16(6), 780-792.

Kim, J. (2019). The impact of different price promotions on customer retention. Journal of Retailing and Consumer Services, 46, 95-102.

Krishna, A., \& Shoemaker, R. W. (1992). Estimating the effects of higher coupon face values on the timing of redemptions, the mix of coupon redeemers, and purchase quantity. Psychology \& Marketing, 9(6), 453-467.

Kukar-Kinney, M., Scheinbaum, A. C., \& Schaefers, T. (2016). Compulsive buying in online daily deal settings: An investigation of motivations and contextual elements. Journal of Business Research, 69(2), 691-699.

Kumar, V., \& Rajan, B. (2012). The perils of social coupon campaigns. MIT Sloan Management Review, 53(4), 13.

Kumar, V., \& Reinartz, W. (2016). Creating enduring customer value. Journal of Marketing, 80(6), 36-68.

Kumar, V., \& Reinartz, W. (2018). Loyalty Programs: Design and Effectiveness. In Customer Relationship Management (pp. 179-205). Springer, Berlin, Heidelberg.

Lee, J. Y., Fang, E., Kim, J. J., Li, X., \& Palmatier, R. W. (2018). The effect of online shopping platform strategies on search, display, and membership revenues. Journal of Retailing, 94(3), 247-264.

Lee, M. K., Shi, N., Cheung, C. M., Lim, K. H., \& Sia, C. L. (2011). Consumer's decision to shop online: The moderating role of positive informational social influence. Information \& Management, 48(6), 185-191.

Lemon, K. N., \& Verhoef, P. C. (2016). Understanding customer experience throughout the customer journey. Journal of Marketing, 80(6), 69-96.

Li, H., Kuo, C., \& Rusell, M. G. (1999). The impact of perceived channel utilities, shopping orientations, and demographics on the consumer's online buying behavior. Journal of Computer-Mediated Communication, 5(2), JCMC521.

Li, L., Li, X., Qi, W., Zhang, Y., \& Yang, W. (2020). Targeted reminders of electronic coupons: using predictive analytics to facilitate coupon marketing. Electronic Commerce Research, 1-30. https://doi.org/10.1007/s10660-020-09405-4(in press) 
Li, Y. M., Liou, J. H., \& Ni, C. Y. (2019). Diffusing mobile coupons with social endorsing mechanism. Decision Support Systems, 117, 87-99.

Liao, C., Chen, J. L., \& Yen, D. C. (2007). Theory of planning behavior (TPB) and customer satisfaction in the continued use of e-service: An integrated model. Computers in Human Behavior, 23(6), 2804-2822.

Liao, S. L., Shen, Y. C., \& Chu, C. H. (2009). The effects of sales promotion strategy, product appeal and consumer traits on reminder impulse buying behaviour. International Journal of Consumer Studies, 33(3), 274-284.

Liao, T. H. (2017). Online shopping post-payment dissonance: Dissonance reduction strategy using online consumer social experiences. International Journal of Information Management, 37(6), 520-538.

Lim, S. H., Lee, S., \& Kim, D. J. (2017). Is online consumers' impulsive buying beneficial for E-commerce companies? An empirical investigation of online consumers' past impulsive buying behaviors. Information Systems Management, 34(1), 85-100.

Ling, K. C., Chai, L. T., \& Piew, T. H. (2010). The effects of shopping orientations, online trust and prior online purchase experience toward customers' online purchase intention. International Business Research, 3(3), 63.

Liu, Y., Li, H., \& Hu, F. (2013). Website attributes in urging online impulse purchase: An empirical investigation on consumer perceptions. Decision Support Systems, 55(3), 829-837.

Lo, L. Y. S., Lin, S. W., \& Hsu, L. Y. (2016). Motivation for online impulse buying: A twofactor theory perspective. International Journal of Information Management, 36(5), 759-772.

Lu, Y., Lu, Y., \& Wang, B. (2012). Effects of dissatisfaction on customer repurchase decisions in e-commerce-an emotion-based perspective. Journal of Electronic Commerce Research, 13(3), 224.

Luo, X. (2005). How does shopping with others influence impulsive purchasing? Journal of Consumer Psychology, 15(4), 288-294.

MacCallum, R. C., \& Austin, J. T. (2000). Applications of structural equation modeling in psychological research. Annual Review of Psychology, 51(1), 201-226.

Mao, W., \& Oppewal, H. (2010). Did I choose the right university? How post-purchase information affects cognitive dissonance, satisfaction and perceived service quality. Australasian Marketing Journal (AMJ), 18(1), 28-35.

Mattila, A. S., \& Wirtz, J. (2008). The role of store environmental stimulation and social factors on impulse purchasing. Journal of Services Marketing, 22(7), 562-567.

Mayer, N. D., \& Tormala, Z. L. (2010). "Think" versus "feel" framing effects in persuasion. Personality and Social Psychology Bulletin, 36(4), 443-454. 
Mellinas, J. P., Nicolau, J. L., \& Park, S. (2019). Inconsistent behavior in online consumer reviews: the effects of hotel attribute ratings on location. Tourism Management, 71, 421-427.

Mills, P., \& Zamudio, C. (2018). Scanning for discounts: examining the redemption of competing mobile coupons. Journal of the Academy of Marketing Science, 46(5), 964-982.

Moon, J., Chadee, D., \& Tikoo, S. (2008). Culture, product type, and price influences on consumer purchase intention to buy personalized products online. Journal of Business Research, 61(1), 31-39.

Muchneeded. Com (2020). "Amazon by the Numbers: Stats, User base \& Fun Facts" Available at: https://muchneeded.com/amazon-statistics/. Accessed on 25 February, 2020

Nayal, P., \& Pandey, N. (2020). Redemption Intention of Coupons: A Meta-Analytical Review and Future Directions. Journal of Promotion Management, 26(3), 372-395.

Niu, H. J. (2013). Cyber peers' influence for adolescent consumer in decision-making styles and online purchasing behavior. Journal of Applied Social Psychology, 43(6), 1228-1237.

Nunnally, J. (1978). Psychometric Methods. New York: McGraw Hill.

Okada, E. M., \& Hoch, S. J. (2004). Spending time versus spending money. Journal of Consumer Research, 31(2), 313-323.

Oliver, R. L., \& Shor, M. (2003). Digital redemption of coupons: Satisfying and dissatisfying effects of promotion codes. Journal of Product and Brand Management, 12(2), 121-134.

Ozer, L., \& Gultekin, B. (2015). Pre-and post-purchase stage in impulse buying: The role of mood and satisfaction. Journal of Retailing and Consumer Services, 22, 71-76.

Pandey, N., \& Maheshwari, V. (2017). Four decades of coupon research in pricing: Evolution, development, and practice. Journal of Revenue and Pricing Management, 16(4), 397-416.

Park, J., Snell, W., Ha, S., \& Chung, T. L. (2011). Consumers' Post-adoption of M-services: Interest in Future M-services Based on Consumer Evaluations of Current M-services. Journal of Electronic Commerce Research, 12(3), 165.

Pechmann, C., Levine, L., Loughlin, S., \& Leslie, F. (2005). Impulsive and self-conscious: Adolescents' vulnerability to advertising and promotion. Journal of Public Policy \& Marketing, 24(2), 202-221.

Phua, J., Jin, S. V., \& Kim, J. J. (2017). Gratifications of using Facebook, Twitter, Instagram, or Snapchat to follow brands: The moderating effect of social comparison, trust, tie strength, and network homophily on brand identification, brand engagement, brand commitment, and membership intention. Telematics and Informatics, 34(1), 412-424.

Poisson, D. C. (2018). The effectiveness of coupons on the restaurant consumers' purchase decision. Journal of Foodservice Business Research, 21(3), 280-296. 
Qu, H., \& Lee, H. (2011). Travelers' social identification and membership behaviors in online travel community. Tourism Management, 32(6), 1262-1270.

Ravula, P., Bhatnagar, A., \& Ghose, S. (2020). Antecedents and consequences of crosseffects: An empirical analysis of omni-coupons. International Journal of Research in Marketing. (In Press)

Reichhart, P., Pescher, C., \& Spann, M. (2013). A comparison of the effectiveness of e-mail coupons and mobile text message coupons for digital products. Electronic Markets, 23(3), 217-225.

Roehm, M. L., Pullins, E. B., \& Roehm Jr, H. A. (2002). Designing loyalty-building programs for packaged goods brands. Journal of Marketing Research, 39(2), 202-213.

Rook, D. W. (1987). The buying impulse. Journal of Consumer Research, 14(2), 189-199.

Rook, D. W., \& Fisher, R. J. (1995). Normative influences on impulsive buying behavior. Journal of Consumer Research, 22(3), 305-313.

Rook, D. W., \& Gardner, M. P. (1993). In the mood: Impulse buying's affective antecedents. Research in Consumer Behavior, 6(7), 1-28.

Rust, R. T., \& Zahorik, A. J. (1993). Customer satisfaction, customer retention, and market share. Journal of Retailing, 69(2), 193-215.

Santos, J., \& Boote, J. (2003). A theoretical exploration and model of consumer expectations, post-purchase affective states and affective behaviour. Journal of Consumer Behaviour: An International Research Review, 3(2), 142-156.

Sarkar, A. (2011). Impact of utilitarian and hedonic shopping values on individual's perceived benefits and risks in online shopping. International Management Review, 7(1), 5865.

Schlosser, A. E., White, T. B., \& Lloyd, S. M. (2006). Converting web site visitors into buyers: how web site investment increases consumer trusting beliefs and online purchase intentions. Journal of Marketing, 70(2), 133-148.

Seock, Y. K., \& Bailey, L. R. (2008). The influence of college students' shopping orientations and gender differences on online information searches and purchase behaviours. International Journal of Consumer Studies, 32(2), 113-121.

Shahin Sharifi, S., \& Rahim Esfidani, M. (2014). The impacts of relationship marketing on cognitive dissonance, satisfaction, and loyalty: the mediating role of trust and cognitive dissonance. International Journal of Retail \& Distribution Management, 42(6), 553-575.

Shank, D. B., \& Robinson, D. T. (2019). Who's responsible? Representatives' autonomy alters customers' emotion and repurchase intentions toward organizations. Journal of Consumer Marketing, 36(1), 155-167. 
Sharp, B., \& Sharp, A. (1997). Loyalty programs and their impact on repeat-purchase loyalty patterns. International Journal of Research in Marketing, 14(5), 473-486.

Sherman, E., Mathur, A., \& Smith, R. B. (1997). Store environment and consumer purchase behavior: mediating role of consumer emotions. Psychology \& Marketing, 14(4), 361-378.

Shiau, W. L., \& Luo, M. M. (2012). Factors affecting online group buying intention and satisfaction: A social exchange theory perspective. Computers in Human Behavior, 28(6), 2431-2444.

Shimp, T. A., \& Kavas, A. (1984). The theory of reasoned action applied to coupon usage. Journal of Consumer Research, 11(3), 795-809.

Silvera, D. H., Lavack, A. M., \& Kropp, F. (2008). Impulse buying: the role of affect, social influence, and subjective wellbeing. Journal of Consumer Marketing, 25(1), 23-33.

Souiden, N., Chaouali, W., \& Baccouche, M. (2019). Consumers' attitude and adoption of location-based coupons: The case of the retail fast food sector. Journal of Retailing and Consumer Services, 47, 116-132.

Spralls III, S. A., Divine, R. L., \& Garver, M. S. (2016). Have the Mobile Coupon Preferences of Millennials Changed? Journal of Promotion Management, 22(6), 792-809.

Stathopoulou, A., \& Balabanis, G. (2016). The effects of loyalty programs on customer satisfaction, trust, and loyalty toward high-and low-end fashion retailers. Journal of Business Research, 69(12), 5801-5808.

Statista (2019), "Number of Amazon Prime members in the United States as of March 2019 (in millions)". Available at "https://www.statista.com/statistics/546894/number-of-amazonprime-paying-members/"'

Stern, H. (1962). The significance of impulse buying today. Journal of Marketing, 26(2), 5962.

Suri, R., Swaminathan, S., \& Monroe, K. B. (2004). Price communications in online and print coupons: An empirical investigation. Journal of Interactive Marketing, 18(4), 74-86.

Sweeney, J. C., Hausknecht, D., \& Soutar, G. N. (2000). Cognitive dissonance after purchase: A multidimensional scale. Psychology \& Marketing, 17(5), 369-385.

Tanford, S., \& Montgomery, R. (2015). The effects of social influence and cognitive dissonance on travel purchase decisions. Journal of Travel Research, 54(5), 596-610.

Teng, C. C., \& Wang, Y. M. (2015). Decisional factors driving organic food consumption: Generation of consumer purchase intentions. British Food Journal, 117(3), 1066-1081.

Thøgersen, J. (2004). A cognitive dissonance interpretation of consistencies and inconsistencies in environmentally responsible behavior. Journal of Environmental Psychology, 24(1), 93-103. 
Van Dolen, W. M., Dabholkar, P. A., \& De Ruyter, K. (2007). Satisfaction with online commercial group chat: the influence of perceived technology attributes, chat group characteristics, and advisor communication style. Journal of Retailing, 83(3), 339-358.

Verhagen, T., \& van Dolen, W. (2011). The influence of online store beliefs on consumer online impulse buying: A model and empirical application. Information \& Management, 48(8), 320-327.

Verhoef, P. C., Kannan, P. K., \& Inman, J. J. (2015). From multi-channel retailing to omnichannel retailing: introduction to the special issue on multi-channel retailing. Journal of Retailing, 91(2), 174-181.

Wang, D., Li, Z., \& Xiao, B. (2019). Social influence in first-time and upgrade adoption. Electronic Commerce Research and Applications, 34, 100834.

Wayne, M. L. (2018). Netflix, Amazon, and branded television content in subscription video on-demand portals. Media, Culture \& Society, 40(5), 725-741.

Webster Jr, F. E. (1965). The "deal-prone" consumer. Journal of Marketing Research, 2(2), 186-189.

Wells, J. D., Parboteeah, V., \& Valacich, J. S. (2011). Online impulse buying: understanding the interplay between consumer impulsiveness and website quality. Journal of the Association for Information Systems, 12(1), 3.

Wilkins, S., Beckenuyte, C., \& Butt, M. M. (2016). Consumers' behavioural intentions after experiencing deception or cognitive dissonance caused by deceptive packaging, package downsizing or slack filling. European Journal of Marketing, 50 (1/2), 213-235

Wilkins, S., Butt, M. M., Shams, F., \& Pérez, A. (2019). Product standardisation in the food service industry: post-purchase attitudes and repurchase intentions of non-Muslims after consuming halal food. Journal of Strategic Marketing, 27(3), 210-226.

Xu, Y., \& Huang, J. S. (2014). Effects of price discounts and bonus packs on online impulse buying. Social Behavior and Personality: An International Journal, 42(8), 1293-1302.

Youn, S., \& Faber, R. J. (2000). Impulse buying: its relation to personality traits and cues. ACR North American Advances. 27, 179-185

Zhang, J., \& Wedel, M. (2009). The effectiveness of customized promotions in online and offline stores. Journal of Marketing Research, 46(2), 190-206.

Zhang, X., Li, S., \& Burke, R. R. (2018). Modeling the effects of dynamic group influence on shopper zone choice, purchase conversion, and spending. Journal of the Academy of Marketing Science, 46(6), 1089-1107. 
Zhang, X., Prybutok, V. R., \& Koh, C. E. (2006). The role of impulsiveness in a TAM-based online purchasing behavior. Information Resources Management Journal (IRMJ), 19(2), 5468.

Zhu, Z., Wang, J., Wang, X., \& Wan, X. (2016). Exploring factors of user's peer-influence behavior in social media on purchase intention: Evidence from QQ. Computers in Human Behavior, 63, 980-987.

\section{List of Tables}

Table 1: Socio-Demographic details of the sample

Table 2: Results of Measurement Model (CFA)

Table 3: Correlation Matrix and $\sqrt{ }$ AVE

Table 4: Structural model results

Table 5: Results of Analysis of Variance test 


\begin{tabular}{|c|c|c|c|c|}
\hline \multicolumn{5}{|c|}{ Table 1: Socio-Demographic details of the sample participated in survey } \\
\hline Variables & Category & Numbers & Percentage & Total \\
\hline \multirow{2}{*}{ Gender } & Female & 145 & 43.81 & \multirow{2}{*}{331} \\
\hline & Male & 186 & 56.19 & \\
\hline \multirow{3}{*}{ Age } & 19 to 22 years & 132 & 39.87 & \multirow{3}{*}{331} \\
\hline & 23 to 28 years & 119 & 35.95 & \\
\hline & 29 to 37 years & 80 & 24.18 & \\
\hline \multirow{2}{*}{ Membership } & Prime member & 154 & 46.53 & \multirow{2}{*}{331} \\
\hline & Non-prime member & 177 & 53.47 & \\
\hline \multirow{6}{*}{$\begin{array}{c}\text { Product } \\
\text { category } \\
\text { purchased }\end{array}$} & Electronic gadgets & 121 & 36.56 & \multirow{6}{*}{331} \\
\hline & Fashion, Clothing & 78 & 23.56 & \\
\hline & Beauty, Health and Grocery & 51 & 15.41 & \\
\hline & Books & 43 & 12.99 & \\
\hline & Sports, Fitness, Bags and Luggage & 29 & 8.76 & \\
\hline & Others & 9 & 2.72 & \\
\hline \multirow{7}{*}{$\begin{array}{c}\text { Purchase } \\
\text { Value during } \\
\text { the } \\
\text { Experiment }\end{array}$} & Rs. $101-200$ (denoted as 1) & 2 & 0.60 & \multirow{7}{*}{331} \\
\hline & Rs. $201-300$ (denoted as 2) & 83 & 25.08 & \\
\hline & Rs. 301 - 400 (denoted as 3) & 83 & 25.08 & \\
\hline & Rs. $401-500$ (denoted as 4) & 44 & 13.29 & \\
\hline & Rs. $501-600$ (denoted as 5) & 57 & 17.22 & \\
\hline & Rs. 601 - 700 (denoted as 6) & 51 & 15.41 & \\
\hline & Above Rs. 700 (denoted as 7) & 11 & 3.32 & \\
\hline
\end{tabular}




\begin{tabular}{|c|c|c|c|c|c|}
\hline \multicolumn{6}{|c|}{ Table 2: Results of Measurement Model (CFA) } \\
\hline Construct & Items & Mean $(s d)$ & $\begin{array}{c}\text { Factor } \\
\text { Loadings }\end{array}$ & $\begin{array}{c}\text { AVE } \\
(\mathrm{MSV}, \mathrm{ASV})\end{array}$ & Sources of the scale \\
\hline \multirow{4}{*}{$\begin{array}{c}\text { Perceived } \\
\text { Impulsiveness }\end{array}$} & PI 1 & $4.15(1.59)$ & $0.939^{* * *}$ & \multirow{4}{*}{$\begin{array}{c}0.933 \\
(0.042,0.027)\end{array}$} & \multirow{4}{*}{$\begin{array}{l}\text { Verhagen and van } \\
\text { Dolen (2011) }\end{array}$} \\
\hline & PI 2 & $4.09(1.58)$ & $0.928^{* * *}$ & & \\
\hline & PI 3 & $4.15(1.60)$ & $0.950^{* * *}$ & & \\
\hline & PI 4 & $4.09(1.51)$ & $0.857^{* * *}$ & & \\
\hline \multirow{3}{*}{$\begin{array}{c}\text { Cognitive Post } \\
\text { Purchase } \\
\text { Dissonance (CPPD) }\end{array}$} & CPPD 1 & $3.96(1.89)$ & $0.960^{* * * *}$ & \multirow{3}{*}{$\begin{array}{c}0.902 \\
(0.035,0.013)\end{array}$} & \multirow{3}{*}{$\begin{array}{c}\text { Shahin Sharifi and } \\
\text { Rahim Esfidani, (2014) }\end{array}$} \\
\hline & CPPD 2 & $4.02(1.90)$ & $0.930^{* * *}$ & & \\
\hline & CPPD 3 & $3.98(1.95)$ & $0.959^{* * *}$ & & \\
\hline \multirow{7}{*}{$\begin{array}{c}\text { Affective Post } \\
\text { Purchase } \\
\text { Dissonance (APPD) }\end{array}$} & APPD 1 & $4.41(1.63)$ & $0.940^{* * * *}$ & \multirow{7}{*}{$\begin{array}{c}0.881 \\
(0.080,0.050)\end{array}$} & \multirow{7}{*}{$\begin{array}{l}\text { Mao and Oppewal } \\
\text { (2010) }\end{array}$} \\
\hline & APPD 2 & $4.48(1.65)$ & $0.932^{* * *}$ & & \\
\hline & APPD 3 & $4.44(1.68)$ & $0.945^{* * *}$ & & \\
\hline & APPD 4 & $4.41(1.62)$ & $0.943^{* * *}$ & & \\
\hline & APPD 5 & $4.33(1.66)$ & $0.945^{* * *}$ & & \\
\hline & APPD 6 & $4.45(1.64)$ & $0.938^{* * *}$ & & \\
\hline & APPD 7 & $4.29(1.59)$ & $0.926^{* * *}$ & & \\
\hline \multirow{3}{*}{$\begin{array}{l}\text { Repurchase } \\
\text { Intention }\end{array}$} & RI 1 & $3.55(2.61)$ & $0.973^{* * *}$ & \multirow{3}{*}{$\begin{array}{c}0.845 \\
(0.080,0.038)\end{array}$} & \multirow{3}{*}{ Khalifa and Liu (2007) } \\
\hline & RI 2 & $3.65(2.16)$ & $0.965^{* * *}$ & & \\
\hline & RI 3 & $3.70(2.21)$ & $0.959^{* * *}$ & & \\
\hline CFA Fit indices: $x 2$ & $\mathrm{f}=1.707$ & $I=0.933$ & $I=0.990$ & ood fit $>0.9$ ); & SEA $=0.046$ (Good fit \\
\hline
\end{tabular}




\begin{tabular}{|l|r|r|r|r|c|}
\hline \multicolumn{7}{|c|}{ Table 3: Correlation Matrix and $\sqrt{ }$ AVE } \\
\hline Variables & $\alpha$ & PI & CPPD & APPD & RI \\
\hline Perceived Impulsiveness (PI) & 0.976 & 0.966 & & & \\
\hline Cognitive Post Purchase Dissonance (CPPD) & 0.965 & -0.054 & 0.950 & & \\
\hline Affective Post Purchase Dissonance (APPD) & 0.981 & -0.206 & 0.187 & 0.938 & \\
\hline Repurchase Intention (RI) & 0.956 & -0.186 & -0.031 & 0.282 & 0.919 \\
\hline$\alpha$ ' denotes Cronbach's Alpha; AVE represents Average Variance Extracted \\
The italicised numbers in the diagonal represents $\sqrt{ }$ AVE \\
Note: All values represent standardised estimates \\
\hline
\end{tabular}




\begin{tabular}{|c|c|c|c|c|}
\hline \multicolumn{5}{|c|}{$\begin{array}{c}\text { Table 4: Structural model results } \\
\end{array}$} \\
\hline Hypothesis & $\begin{array}{l}\text { Exogenous factor } \\
\text { (Independent) }\end{array}$ & Endogenous factor (Dependent) & $\begin{array}{l}\text { Standardised } \\
\text { Coefficient }\end{array}$ & $\mathbf{r}^{2}$ \\
\hline Hypothesis 1 & \multirow{2}{*}{$\begin{array}{c}\text { Coupon } \\
\text { Value }\end{array}$} & Purchase value & $0.210^{* * *}$ & 0.310 \\
\hline Hypothesis 2 & & Perceived Impulsiveness & $0.622 * * *$ & 0.469 \\
\hline Hypothesis 3 & \multirow{2}{*}{ Peer Influence } & Purchase value & $0.286 * * *$ & 0.310 \\
\hline Hypothesis 4 & & Perceived Impulsiveness & $0.274 * * *$ & 0.469 \\
\hline Hypothesis 5 & \multirow{2}{*}{$\begin{array}{c}\text { Portal } \\
\text { Membership }\end{array}$} & Purchase value & $0.428 * * *$ & 0.310 \\
\hline Hypothesis 6 & & Perceived Impulsiveness & $0.082 * *$ & 0.469 \\
\hline Hypothesis 7 & \multirow{2}{*}{$\begin{array}{l}\text { Purchase } \\
\text { Value }\end{array}$} & Cognitive Post Purchase Dissonance & $0.348 * * *$ & 0.117 \\
\hline Hypothesis 8 & & Affective Post Purchase Dissonance & $0.300 * * *$ & 0.154 \\
\hline Hypothesis 9 & \multirow{2}{*}{$\begin{array}{c}\text { Perceived } \\
\text { Impulsiveness }\end{array}$} & Cognitive Post Purchase Dissonance & $-0.145^{\mathrm{ns}}$ & 0.117 \\
\hline Hypothesis 10 & & Affective Post Purchase Dissonance & $0.191 * * *$ & 0.154 \\
\hline Hypothesis 11 & $\begin{array}{c}\text { Cognitive Post } \\
\text { Purchase Dissonance }\end{array}$ & Repurchase Intention & $-0.434 * * *$ & \multirow{4}{*}{0.547} \\
\hline Hypothesis 12 & $\begin{array}{l}\text { Affective Post Purchase } \\
\text { Dissonance }\end{array}$ & Repurchase Intention & $-0.208 * * *$ & \\
\hline Hypothesis 13 & $\begin{array}{l}\text { Complimentary Coupon } \\
\text { X Cognitive Post } \\
\text { Purchase Dissonance } \\
\end{array}$ & Repurchase Intention & $0.548 * * *$ & \\
\hline Hypothesis 14 & $\begin{array}{l}\text { Complimentary Coupon } \\
\text { X Affective Post } \\
\text { Purchase Dissonance }\end{array}$ & Repurchase Intention & $0.007^{\mathrm{ns}}$ & \\
\hline \multicolumn{5}{|c|}{$\begin{array}{l}\text { *** } \text { represents values significant at } 99 \% \text { confidence level; } \\
{ }^{* *} \text { represents values significant at } 95 \% \text { level; } \\
\text { ns represents non-significant relationship }\end{array}$} \\
\hline \multicolumn{5}{|c|}{$\begin{array}{l}\text { Fit Indices: } \varkappa^{2} / \mathrm{df}=2.559(\text { Good fit }<5) ; \mathrm{GFI}=0.889, \mathrm{CFI}=0.966,(\text { Good fit }>0.85) ; \text { RMSEA=0.069 }(\text { Good } \\
\text { fit }<0.08)\end{array}$} \\
\hline
\end{tabular}




\begin{tabular}{|c|c|c|c|c|}
\hline \multicolumn{5}{|c|}{ Table 5: Results of Analysis of Variance test } \\
\hline Variables & $\begin{array}{c}\text { Coupon } \\
\text { Value }\end{array}$ & $\begin{array}{c}\text { Prime } \\
\text { Membership }\end{array}$ & $\begin{array}{c}\text { Complimentary } \\
\text { coupon }\end{array}$ & $\begin{array}{c}\text { Social } \\
\text { Influence }\end{array}$ \\
\hline Purchase Value & $022.851^{* * *}$ & $078.503^{* * *}$ & $000.493^{\text {ns }}$ & $024.092^{* * * *}$ \\
\hline $\begin{array}{l}\text { Perceived Impulsive } \\
\text { Action }\end{array}$ & $224.715^{* * * *}$ & $007.250^{* * *}$ & $000.014^{\mathrm{ns}}$ & $024.186^{* * *}$ \\
\hline APPD & $003.629^{\mathrm{ns}}$ & $002.448^{\mathrm{ns}}$ & $000.598^{\text {ns }}$ & $156.612^{* * *}$ \\
\hline CPPD & $000.098^{\mathrm{ns}}$ & $013.433^{* * *}$ & $003.986^{* *}$ & $014.100^{* * *}$ \\
\hline Repurchase Intention & $001.776^{\mathrm{ns}}$ & $000.550^{\mathrm{ns}}$ & $086.347^{* * *}$ & $013.174^{* * *}$ \\
\hline $\begin{array}{l}\text { All values represent } \mathrm{F} \\
\mathrm{APPD}=\text { Affective Pos } \\
\mathrm{CPPD}=\text { Cognitive Po } \\
{ }^{* * *} \text { represent values sig } \\
{ }^{* *} \text { represent values siq } \\
\text { ns represent values no }\end{array}$ & $\begin{array}{l}\text { ues in ANO } \\
\text { rrchase Diss } \\
\text { archase Dis } \\
\text { cant at } 99 \% \\
\text { cant at } 95 \% \\
\text { nificant at }\end{array}$ & $\begin{array}{l}\text { A table } \\
\text { hance; } \\
\text { nance } \\
\text { evel } \\
\text { evel } \\
\% \text { level }\end{array}$ & & \\
\hline
\end{tabular}




\section{List of Figures:}

Figure 1: Conceptual model of the study

Figure 2: Validated model of the study

Figure 3: Effect of complimentary coupons in CPPD -> PI

Figure 4: Effect of complimentary coupons in APPD -> PI 


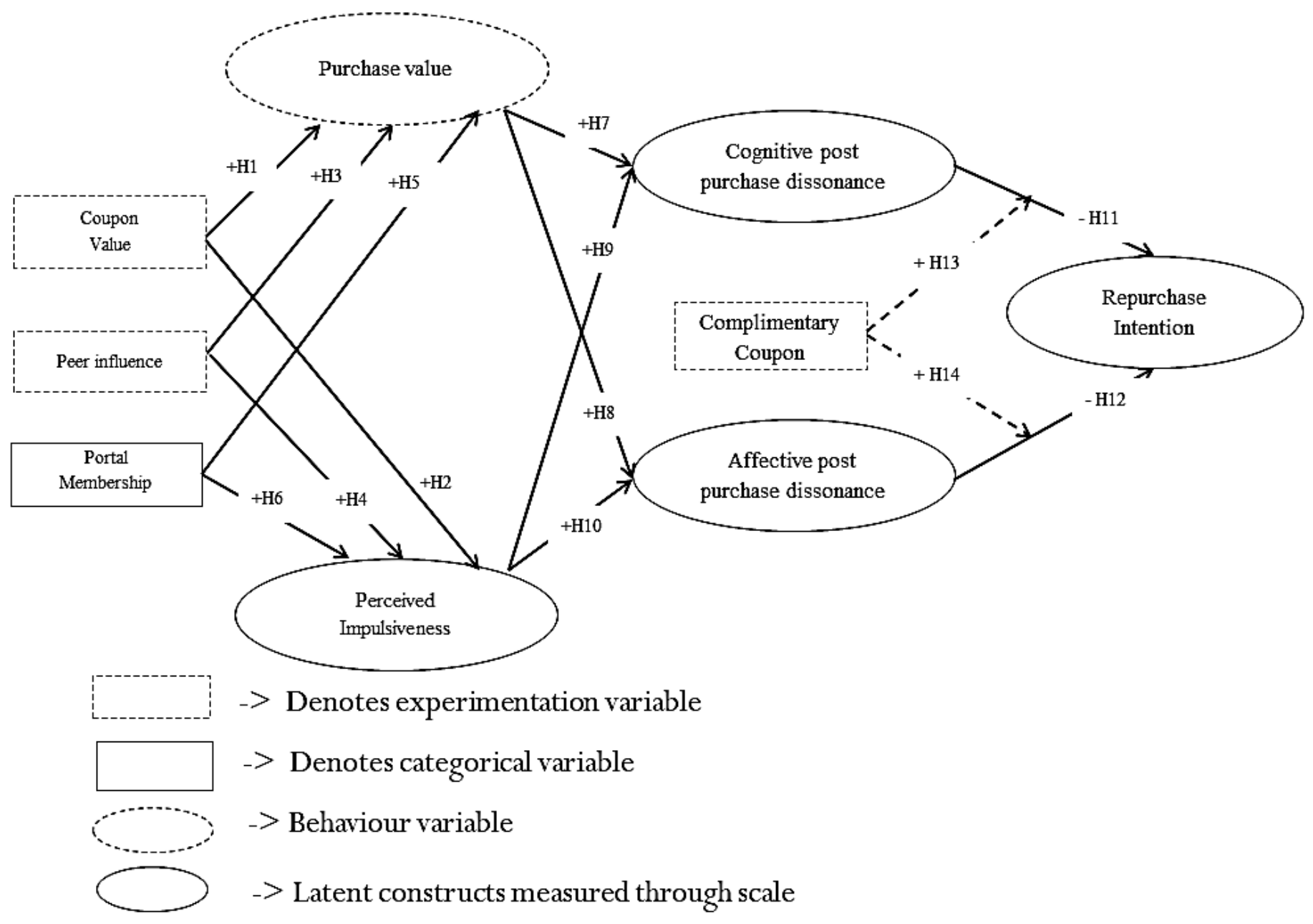

Figure 1: Conceptual model of the study 


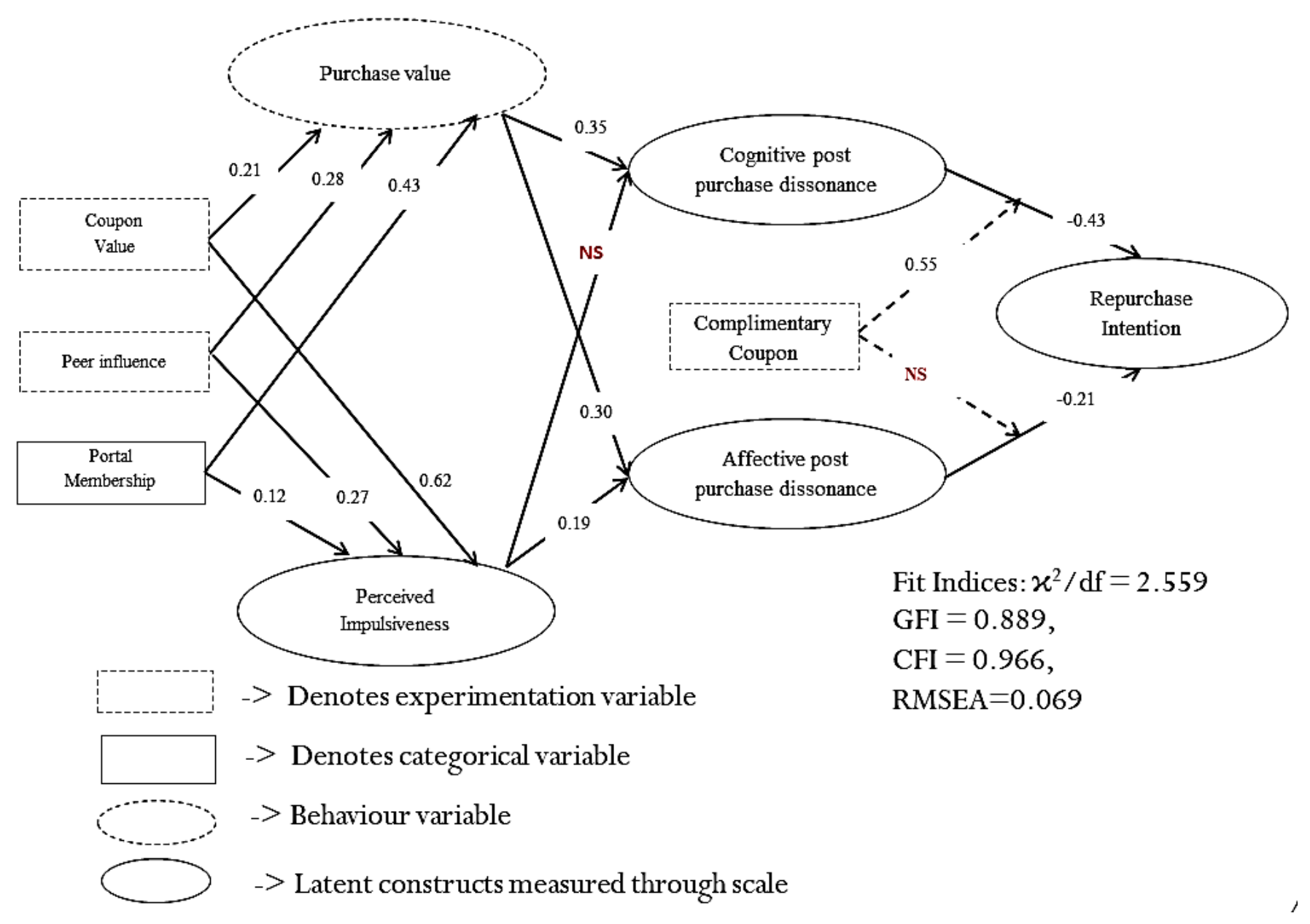

Figure 2: Validated model with results (NS shows insignificant paths; remaining all paths significant at $p<0.001$ ) 


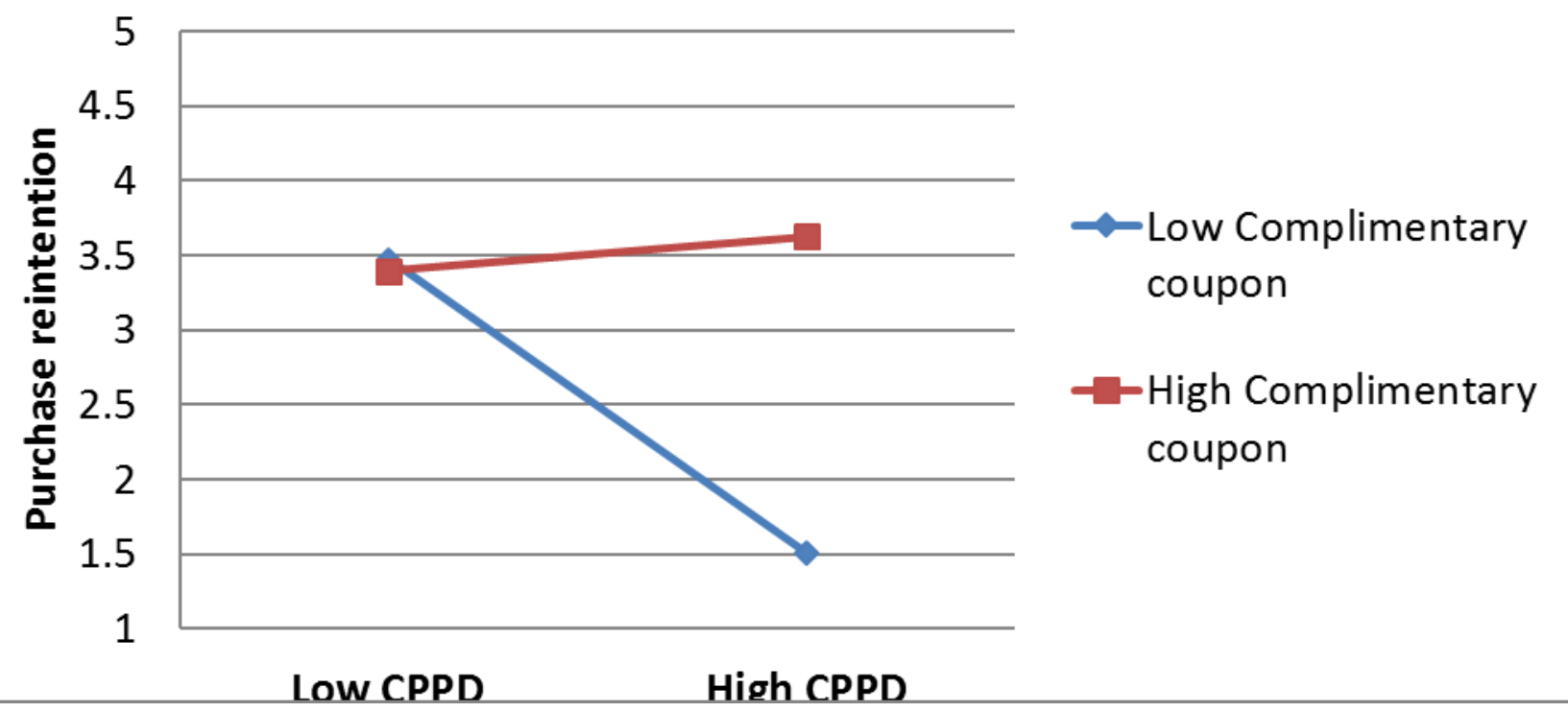

Figure 3: Effect of complimentary coupons in CPPD -> PI 


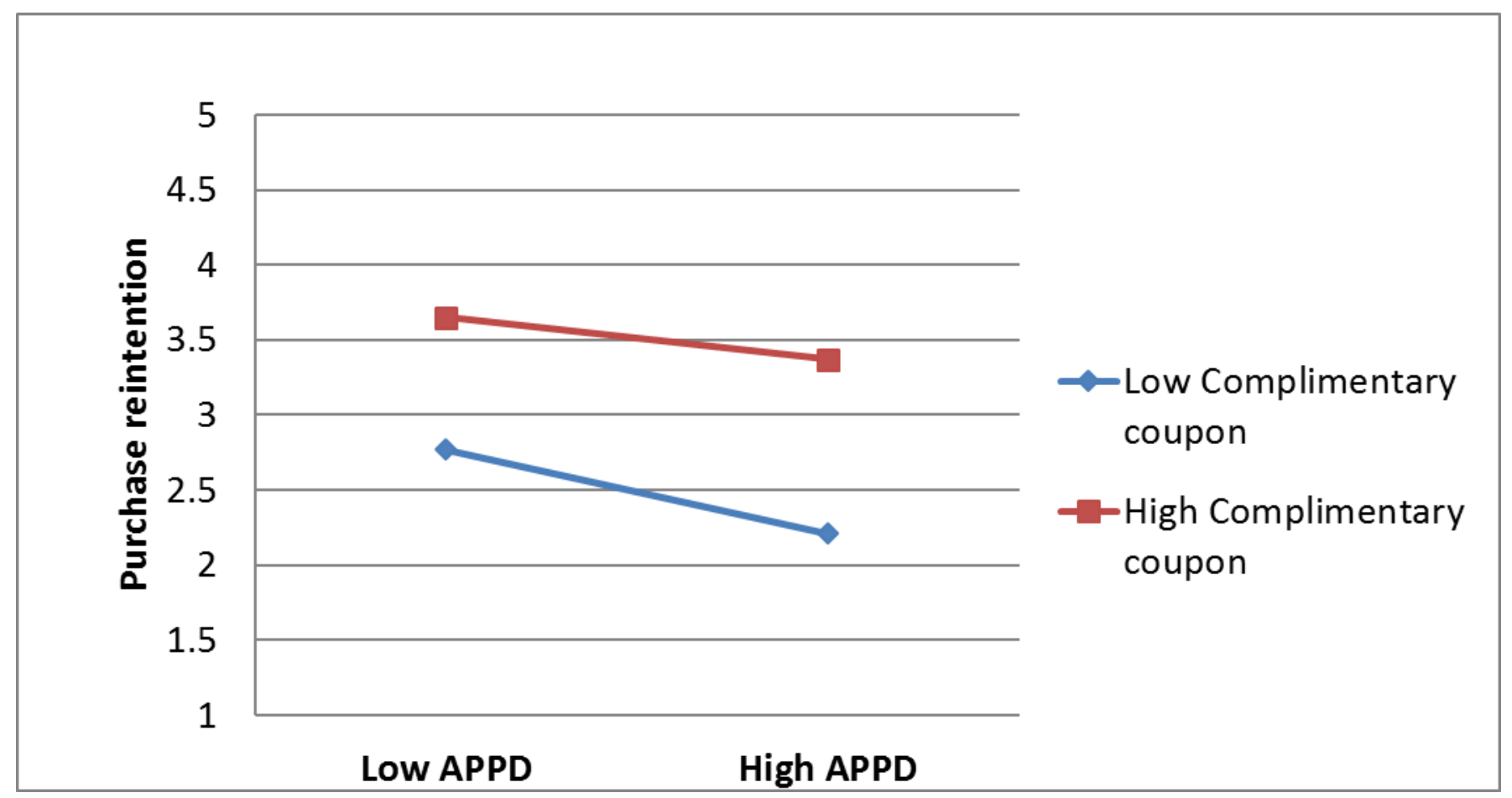

Figure 4: Effect of complimentary coupons in APPD -> PI 
Appendix 1: Experimental design of the study

\begin{tabular}{|c|c|c|c|c|c|c|c|}
\hline \multicolumn{8}{|c|}{ Day 1} \\
\hline Experimentation & $\begin{array}{c}\text { Experiment variable 1: } \\
\text { Coupon value }\end{array}$ & N1 & N2 & $\begin{array}{l}\text { Experiment variable 2: } \\
\text { Peer influence }\end{array}$ & $\begin{array}{l}\text { Experiment variable 3: } \\
\text { Complimentary coupons }\end{array}$ & Block & $\begin{array}{l}\text { Block } \\
\text { design }\end{array}$ \\
\hline \multirow{4}{*}{$\begin{array}{l}68 \text { minutes of } \\
\text { experiment }\end{array}$} & $\begin{array}{l}\text { Condition 2: Coupon } \\
\text { value Rs. } 200 \text { circulated }\end{array}$ & 48 & 46 & $\begin{array}{l}\text { Condition 1: Purchases made } \\
\text { individually (without any peers) }\end{array}$ & $\begin{array}{l}\text { Condition 1: No } \\
\text { complimentary coupons } \\
\text { issued after the } \\
\text { experiment }\end{array}$ & 1 & 211 \\
\hline & $\begin{array}{l}\text { Condition 2: Coupon } \\
\text { value Rs. } 200 \text { circulated }\end{array}$ & 46 & 42 & $\begin{array}{l}\text { Condition 1: Purchases made } \\
\text { individually (without any peers) }\end{array}$ & $\begin{array}{c}\text { Condition 2: Rs. } 100 \\
\text { complimentary coupons } \\
\text { issued after the } \\
\text { experiment }\end{array}$ & 2 & 212 \\
\hline & $\begin{array}{l}\text { Condition 2: Coupon } \\
\text { value Rs. } 200 \text { circulated }\end{array}$ & 41 & 40 & $\begin{array}{c}\text { Condition 2: Purchases made with } \\
\text { peer groups }\end{array}$ & $\begin{array}{c}\text { Condition 1: No } \\
\text { complimentary coupons } \\
\text { issued after the } \\
\text { experiment }\end{array}$ & 3 & 221 \\
\hline & $\begin{array}{c}\text { Condition 2: Coupon } \\
\text { value Rs. } 200 \text { circulated }\end{array}$ & 48 & 44 & $\begin{array}{c}\text { Condition 2: Purchases made with } \\
\text { peer groups }\end{array}$ & $\begin{array}{c}\text { Condition 2: Rs. } 100 \\
\text { complimentary coupons } \\
\text { issued after the } \\
\text { experiment }\end{array}$ & 4 & 222 \\
\hline \multicolumn{8}{|c|}{ Day 2} \\
\hline & $\begin{array}{l}\text { Condition 1: Coupon } \\
\text { value Rs. } 100 \text { circulated }\end{array}$ & 43 & 37 & $\begin{array}{l}\text { Condition 1: Purchases made } \\
\text { individually (without any peers) }\end{array}$ & $\begin{array}{c}\text { Condition 1: No } \\
\text { complimentary coupons } \\
\text { issued after the } \\
\text { experiment }\end{array}$ & 5 & 111 \\
\hline & $\begin{array}{c}\text { Condition 1: Coupon } \\
\text { value Rs. } 100 \text { circulated }\end{array}$ & 46 & 41 & $\begin{array}{l}\text { Condition 1: Purchases made } \\
\text { individually (without any peers) }\end{array}$ & $\begin{array}{c}\text { Condition 2: Rs. } 100 \\
\text { complimentary coupons } \\
\text { issued after the } \\
\text { experiment }\end{array}$ & 6 & 112 \\
\hline
\end{tabular}




\begin{tabular}{|l|c|c|c|c|c|c|}
\hline $\begin{array}{c}54 \text { minutes of } \\
\text { experimentation }\end{array}$ & $\begin{array}{c}\text { Condition 1: Coupon } \\
\text { value Rs. 100 circulated }\end{array}$ & 44 & 39 & $\begin{array}{c}\text { Condition 2: Purchases made with } \\
\text { peer groups }\end{array}$ & $\begin{array}{c}\text { Condition 1: No } \\
\text { complimentary coupons } \\
\text { issued after the } \\
\text { experiment }\end{array}$ & 7 \\
\cline { 2 - 6 } & $\begin{array}{c}\text { Condition 1: Coupon } \\
\text { value Rs. 100 circulated }\end{array}$ & 48 & 42 & $\begin{array}{c}\text { Condition 2: Purchases made with } \\
\text { peer groups }\end{array}$ & $\begin{array}{c}\text { Condition 2: Rs. 100 } \\
\text { complimentary coupons } \\
\text { issued after the } \\
\text { experiment }\end{array}$ & 8 \\
122 \\
N1 refers to the number of study participants who are allotted to the block \\
N2 refers to the number of study participants who involved in the experiment by using the coupons \\
\hline
\end{tabular}




\section{Appendix 2: Variables with measurement scales}

\begin{tabular}{|c|c|}
\hline Explanation & Items \\
\hline \multicolumn{2}{|c|}{ Perceived Impulsiveness } \\
\hline $\begin{array}{l}\text { Impulse buying can be defined as "an unplanned purchase" that is } \\
\text { characterized by "(1) relatively rapid decision-making, and } \\
\text { (2) a subjective bias in favour of immediate possession" " (Rook } \\
\text { and Gardner, 1993, p. 3; see also Rook, 1987; Rook \& Hoch, 1985) }\end{array}$ & $\begin{array}{l}\text { 1. My purchase was spontaneous. } \\
\text { 2. My purchase was unplanned. } \\
\text { 3. Before visiting the site, I did not have the intention to do this purchase. } \\
\text { 4. I could not resist to do this purchase at the site }\end{array}$ \\
\hline \multicolumn{2}{|c|}{ Cognitive Post Purchase Dissonance (CPPD) } \\
\hline \multicolumn{2}{|c|}{ Affective Post Purchase Dissonance (APPD) } \\
\hline $\begin{array}{l}\text { Affective post purchase dissonance can be defined as a discomfort } \\
\text { in emotional feel that arises after any purchase action. } \\
\text { (Mao and Oppewal, 2010) }\end{array}$ & $\begin{array}{l}\text { By my choice of purchase } \\
\text { 1. I had left myself down } \\
\text { 2. I feel annoyed } \\
\text { 3. I feel scared } \\
\text { 4. I feel frustrated } \\
\text { 5. I feel depressed } \\
\text { 6. I feel uneasy } \\
\text { 7. I feel disappointed with myself }\end{array}$ \\
\hline \multicolumn{2}{|c|}{ Repurchase Intention } \\
\hline $\begin{array}{l}\text { Repurchase intention is defined as the intention to repeatedly } \\
\text { purchase a particular product or service over time }\end{array}$ & $\begin{array}{l}\text { 1. Anticipate to repurchase in the near future } \\
\text { 2. Likely to repurchase in the near future } \\
\text { 3. Expect to repurchase in the near future }\end{array}$ \\
\hline \multicolumn{2}{|r|}{ Coupon Value } \\
\hline To understand the effect of increase in coupon value towards the & Experimental variable measured with "high value and low value" coupons \\
\hline
\end{tabular}




\begin{tabular}{|l|l|}
\hline investigated variables. & \multicolumn{1}{|c|}{ Peer Influence } \\
\hline \multicolumn{2}{|c|}{ Portal Membership } \\
\hline $\begin{array}{l}\text { To understand the effect of peers and friends in purchase } \\
\text { environment }\end{array}$ & $\begin{array}{l}\text { Experimental variable measured with "with peer group and individual } \\
\text { buying” coupons }\end{array}$ \\
\hline \multicolumn{2}{|c|}{ Complimentary coupon } \\
\hline $\begin{array}{l}\text { To understand the effect of portal registrations and membership } \\
\text { towards the investigated variables }\end{array}$ & $\begin{array}{l}\text { Categorical variable with question "I am an Amazon Prime member/ I am } \\
\text { not an Amazon Prime Member" }\end{array}$ \\
\hline $\begin{array}{l}\text { To understand the effect of complimentary coupons on reduce post } \\
\text { purchase dissonance }\end{array}$ & $\begin{array}{l}\text { Experimental variable measured with "Complimentary coupons issued } \\
\text { post purchase experiment/no complimentary coupons issued post purchase } \\
\text { experiment" }\end{array}$ \\
\hline
\end{tabular}

